\title{
Desirable plant cell wall traits for higher-quality miscanthus lignocellulosic biomass
}

\author{
Ricardo M. F. da Costa ${ }^{1,4^{*}}$ (D), Sivakumar Pattathi ${ }^{2,5}$, Utku Avci ${ }^{2,6}$, Ana Winters ${ }^{1}$, Michael G. Hahn ${ }^{2,3}$ \\ and Maurice Bosch ${ }^{1 *}$ (B)
}

\begin{abstract}
Background: Lignocellulosic biomass from dedicated energy crops such as Miscanthus spp. is an important tool to combat anthropogenic climate change. However, we still do not exactly understand the sources of cell wall recalcitrance to deconstruction, which hinders the efficient biorefining of plant biomass into biofuels and bioproducts.

Results: We combined detailed phenotyping, correlation studies and discriminant analyses, to identify key significantly distinct variables between miscanthus organs, genotypes and most importantly, between saccharification performances. Furthermore, for the first time in an energy crop, normalised total quantification of specific cell wall glycan epitopes is reported and correlated with saccharification.

Conclusions: In stems, lignin has the greatest impact on recalcitrance. However, in leaves, matrix glycans and their decorations have determinant effects, highlighting the importance of biomass fine structures, in addition to more commonly described cell wall compositional features. The results of our interrogation of the miscanthus cell wall promote the concept that desirable cell wall traits for increased biomass quality are highly dependent on the target biorefining products. Thus, for the development of biorefining ideotypes, instead of a generalist miscanthus variety, more realistic and valuable approaches may come from defining a collection of specialised cultivars, adapted to specific conditions and purposes.
\end{abstract}

Keywords: Bioenergy, Biomass, Carbohydrate, Cell wall, Glycan, Lignin, Lignocellulose, Miscanthus, Recalcitrance

\section{Background}

Following global trends, in the last decade, the World Bank has implemented a series of measures to severely limit and eventually stop financing fossil fuel-related projects. Firstly, coal-fired plants ceased to be financed [1], and more recently, the World Bank further announced it would also stop financing oil and gas exploration and extraction from 2019 onwards [2]. These decisions suggest that international monetary organisations are sending the message that fossil fuel resources are part of an antiquated technology, with reduced investment

\footnotetext{
*Correspondence: dacosta.rmf@gmail.com; mub@aber.ac.uk 1 Institute of Biological, Environmental and Rural Sciences, Aberystwyth University, Plas Gogerddan, Aberystwyth, Ceredigion SY23 3EE, UK Full list of author information is available at the end of the article
}

attractiveness. This shift in investment strategy also reaffirms the perception that fossil fuels pose a substantial threat to the global environment, and that weaning ourselves from these resources, as a society, will benefit the reduction of greenhouse gas emissions (GGEs) and mitigation of anthropogenic climate change. Indeed, even multinational petrochemical companies, such as Exxon and Shell, do not dispute the links between their products and anthropogenic climate change [3, 4]. In late 2018, the United Nations Intergovernmental Panel on Climate Change (IPCC) issued a special report on the benefits of limiting global warming to $1.5^{\circ} \mathrm{C}$, instead of the previous goal of $2{ }^{\circ} \mathrm{C}$ above pre-industrial levels [5]. In order to achieve this aim, the IPCC recommended that, among other measures, by 2050 , up to $85 \%$ of global electricity must be supplied by renewable resources, 
including energy crops. In fact, the report went further as it stated that up to 7 million $\mathrm{km}^{2}$ of land-an area almost the size of Australia-would be needed for energy crops. Although some have argued that land-use change for the production of energy crops may increase GGEs [6], this claim is essentially valid only for first-generation cornbased ethanol production, and for the cases where forest and grassland are being diverted to biofuel production. A viable alternative to achieve a large proportion of the IPCC target of 7 million $\mathrm{km}^{2}$ without extensive land-use change is the utilisation of second-generation lignocellulosic feedstocks, which are non-food resources that can be produced with high yields in marginal land [7] - abandoned agricultural land, degraded land, reclaimed land and wasteland. Furthermore, a large-scale industry based on lignocellulose also represents a more sustainable alternative to petrochemical pathways, as released carbon is balanced by photosynthetic capture [8]. From an economic perspective, such a model would still be able to generate new job opportunities [9], and as novel biomass conversion processes emerge, the potential for lignocellulosic biomass valorisation is rapidly increasing [10-12].

Biomass from Miscanthus spp. has long been considered as a promising lignocellulosic feedstock for biorefining applications [13-16]. Reasons for this have to do with the fact that miscanthus crops have high biomass yields, wide climatic versatility and are suitable for cultivation on marginal land, while requiring very low chemical inputs [16-19]. Moreover, particularly for triploid miscanthus hybrids, these crops have vigorous growth and although there is considerable genotypic diversity, Miscanthus spp. generally exhibit good abiotic stress tolerance [20-22].

Plant cell walls make up most of lignocellulosic biomass, and the miscanthus cell wall, similar to that of other grass energy crops, contains large amounts of polymerised sugars, which may be used to produce biofuels and other bioproducts. However, these sugars are included in very complex molecular structures. Carbohydrates in miscanthus lignocellulosic biomass consist of cellulose, a high abundance of xylans (arabinoxylan, AX; glucuronoarabinoxylan, GAX), a low percentage of xyloglucan (XG) and mixed-linkage $1 \rightarrow 3,1 \rightarrow 4$ - $\beta$-glucan (MLG) and small amounts of pectins (homogalacturonan, HG; rhamnogalacturonan-I and -II, RG-I, RG-II) and arabinogalactan-containing polysaccharides and arabinogalactan proteins, AG, AGPs [23]. Additionally, lignin, which is a complex phenolic heteropolymer that typically comprises the second most abundant polymer in miscanthus cell walls, and acetate and hydroxycinnamates (HCAs), which occur as substituents of the main cell wall polymers, are non-carbohydrate components incorporated in miscanthus lignocellulosic biomass [23].
Understanding this plethora of cell wall components, which on their own are already complex, is further complicated by the fact that even within the same miscanthus variety, biomass from different organs or maturity stages may present substantial differences in their cell wall architecture, as our previous work has suggested [22-24]. Specifically, relative abundances of cell wall components and their fine structure are variable, and we still have limited understanding of the processes involved in interconnecting the cell wall components into different matrices according to the functional requirements of the organ and tissue they constitute $[11,25]$. This immense compositional and structural complexity of the plant cell wall is deemed to have distinct impacts on biomass deconstruction, and this is the main reason why the exact basis and mechanisms of cell wall recalcitrance to deconstruction have not yet been completely understood.

Here, we present a study on the cell wall assembly of various genotypes from the two main species of miscanthus, Miscanthus sinensis and M. sacchariflorus, as well as from hybrids between the two species, including the predominant commercially grown triploid genotype of $M . \times$ giganteus. In an effort to provide fundamental knowledge about commelinoid monocot cell walls and address its resistance to deconstruction, we set out to identify cell wall traits that are simultaneously relevant for recalcitrance and distinctive between miscanthus biomasses with high or low saccharification performances. The findings of our study will help in setting and refining objectives for the breeding of miscanthus varieties with improved biorefining capabilities, thereby reducing downstream pretreatment and hydrolysis costs.

\section{Methods}

\section{Plant biomass}

From a previously described field trial [24], eight miscanthus accessions were selected: the predominant commercially grown variety $M . \times$ giganteus (gig01), a second $M$. $\times$ giganteus (hyb03; 64\% M. sinensis, 36\% M. sacchariflorus [26]), M. sinensis $(\sin 08, \sin 09, \sin 11, \sin 13, \sin 15)$ and $M$. sacchariflorus (sac01). Further information on the ploidy of each accession is provided elsewhere [24]. For each genotype, a single tiller with representative thickness and minimum length of three-quarters of total plant height (excluding rhizomes and inflorescences) was randomly collected from three replicate plots. All collected tillers were harvested from mature plants: 18 weeks after emergence, when growth had mostly ceased (peak biomass); 42 weeks after emergence, when plants were senesced. After collection, samples were frozen, freezedried, stem and leaf (including sheath) were separated, and individually ground to a particle size between 0.18 and $0.85 \mathrm{~mm}$. Subsequently, purified cell wall material 
(CWM) was prepared as described elsewhere [27]. Briefly, the biomass was subjected to a series of organic solvent washes, followed by $\alpha$-amylase treatment. This CWM was used for all ensuing compositional analyses.

\section{Saccharification and monosaccharide analyses}

Total monosaccharide quantitation was performed via a method based on Saeman hydrolysis, as previously described [23]. Generally, the method consisted of adding $\mathrm{H}_{2} \mathrm{SO}_{4}$ to the CWM samples at $30{ }^{\circ} \mathrm{C}$ for $1 \mathrm{~h}$, and then diluting the hydrolysate to $4 \% \mathrm{H}_{2} \mathrm{SO}_{4}(\mathrm{w} / \mathrm{w})$ and placing it in an autoclave at $121{ }^{\circ} \mathrm{C}$ for $1 \mathrm{~h}$.

Our aim was to determine the impact of cell wall features on its deconstruction; therefore, to avoid masking of recalcitrance differences, no biomass pretreatment was employed. CWM digestibility was assessed via enzymemediated hydrolysis and quantitation of released monosaccharides. The enzyme cocktail consisted of a mixture of Celluclast (NS 50013; cellulase) and Novozyme 188 (NS 50010; $\beta$ glucosidase) at a 4:1 ratio (both obtained from Novozymes, Bagsvaerd, Denmark). Per each CWM sample the added mixture comprised of $997 \mu \mathrm{L}$ of KOAc buffer at $0.025 \mathrm{M}(\mathrm{pH}=5.6), 2.4 \mu \mathrm{L}$ of Celluclast and $0.6 \mu \mathrm{L}$ of Novozyme 188 , with added sodium azide at $0.04 \%(\mathrm{w} / \mathrm{v})$ to inhibit microbial growth. Samples were incubated at $50{ }^{\circ} \mathrm{C} / 150 \mathrm{rpm}$ for $36 \mathrm{~h}$. Cellulase loadings were in excess of 14 filter paper units per gram (FPU/g) of CWM, based on a cellulase activity value of $60 \mathrm{FPU} / \mathrm{mL}$ for Celluclast. High enzyme loads ensured that enzymes were not limiting to the reaction.

The hydrolysates resulting from acid hydrolysis and enzymatic saccharification were analysed by high-performance anion-exchange chromatography with pulsed amperometric detection (HPAEC-PAD), on a CarboPac SA10 $(4 \times 250 \mathrm{~mm})$ column, operating on a 14 -min per

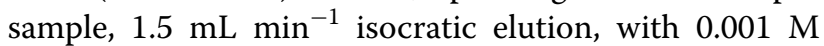
$\mathrm{KOH}$ [23]. Calibration standards were used for monosaccharide identification and quantitation.

\section{Determination of lignin, acetyl and hydroxycinnamoyl esters}

Lignin content determinations were performed using the acetyl bromide procedure as previously described [24]. Acetate determination was achieved by alkaline saponification ( $\left.0.1 \mathrm{M} \mathrm{KOH} ; 16 \mathrm{~h} ; 21^{\circ} \mathrm{C} / 150 \mathrm{rpm}\right)$ followed by high-performance liquid chromatography-refractiveindex detection. Ester-linked hydroxycinnamic acids (HCAs) were released via alkaline saponification with $\left.1 \mathrm{M} \mathrm{KOH} \mathrm{(16} \mathrm{h;} 21^{\circ} \mathrm{C} / 150 \mathrm{rpm}\right)$. Monomeric ferulic and $p$-coumaric acids were identified and quantified, using authentic standards on a reversed-phase high-performance liquid chromatography system with a diode array detector. Both procedures are described in detail elsewhere [23].

\section{Glycome profiling}

The glycome profiling study and auxiliary phenol-sulphuric acid assays, were carried out as stated elsewhere $[28,29]$. Briefly, a sequential series of increasingly harsh extractions were carried out on the CWM employing the following solutions: $0.05 \mathrm{M}$ ammonium oxalate, $0.05 \mathrm{M}$ sodium carbonate (with $0.5 \%$ (w/v) sodium borohydride), $1 \mathrm{M} \mathrm{KOH}, 4 \mathrm{M} \mathrm{KOH}$, acidic sodium chlorite and $4 \mathrm{M}$ $\mathrm{KOH} \mathrm{PC}$ (post-chlorite treatment). All $\mathrm{KOH}$ reagents were supplemented with $1 \%(\mathrm{w} / \mathrm{v})$ sodium borohydride. Each resulting cell wall extract was neutralised, dialysed and lyophilised and then screened using a suite of 155 glycan-directed monoclonal antibodies (mAbs), obtained from the Complex Carbohydrate Research Center laboratory stocks (CCRC, JIM and MAC series) or from BioSupplies (Australia) (BG1, LAMP). More details regarding the glycan-directed $\mathrm{mAb}$ classes are available in Additional file 1.

\section{Data normalisation and analysis}

A previously reported reference glycome profile for the miscanthus cell wall [23] revealed that the most significant variability between the studied genotypes could be summarised using seven glycan-directed mAbs, which recognise epitopes in xyloglucans, CCRC-M87 [30]; xylans, CCRC-M154, CCRC-M144 and CCRC-M137 [31]; MLG, BG1 [32]; arabinogalactans, CCRC-M7 [33, 34] and homogalacturonan, CCRC-M38 [28]. For each sequential extract produced from each cell wall sample, of a given genotype and harvest, the net optical density (OD) of each of the seven above-mentioned mAbs was used as a measure of binding intensity of the respective $\mathrm{mAb}$. These OD values were normalised to the amount of recovered carbohydrate in that particular cell wall extract. Subsequently, normalised epitope abundances from the six extracts were summed to obtain a single normalised value representing the total epitope abundance for each specific mAb $(N)$. Calculations are summarised in the following equation:

$$
N_{k}=\sum_{i=1}^{6} \frac{\mathrm{OD} k_{i} \times R_{i}}{E_{i}},
$$

where, for each $k$ mAb (CCRC-M87, CCRC-M154, CCRC-M144, CCRC-M137, BG1, CCRC-M7, CCRC$\mathrm{M} 38), O D k_{i}$ is the optical density obtained for $\mathrm{mAb} k$ in extract $i$ (oxalate, carbonate, $1 \mathrm{M} \mathrm{KOH}, 4 \mathrm{M} \mathrm{KOH}$, chlorite and $4 \mathrm{M} \mathrm{KOH} \mathrm{PC);} R_{i}$ is the released carbohydrate in extract $i$ per $\mathrm{g}$ of $\mathrm{CWM}$, estimated as glucose equivalents by the phenol-sulphuric acid assay $\left(\mathrm{mg} \mathrm{g}^{-1} \mathrm{CWM}\right) ; E_{i}$ is 
the carbohydrate concentration in the total CWM extract $i$, estimated as glucose equivalents, by the phenol-sulphuric acid assay $\left(\mathrm{mg} \mathrm{mL}^{-1}\right)$.

All descriptive statistics, ANOVA, Tukey's tests and correlations were calculated at a $5 \%$ significance level $(\alpha=0.05)$. Effect sizes were calculated as eta-squared statistics [35, 36]: $\eta^{2}=\mathrm{SS}_{\text {effect }} / \mathrm{SS}_{\text {total }}$ (where $\mathrm{SS}$ is the sum of squares). Agglomerative hierarchical clustering of the genotypes, according to the measured cell wall traits, was performed using the 'hclust' R-function (R Development Core Team, 2017).

\section{X-ray micro computed tomography scanning}

For seven of the eight genotypes used here, a representative tiller was collected at the senesced stage. For each selected tiller, a mid-section of the third internode was taken for X-ray micro computed tomography scanning $(\mu \mathrm{CT})$ and placed in a sample holder. The holders were loaded into the sample carousel of a $\mu$ CT100 scanner (Scanco Medical, Switzerland) [37]. Internode sections were scanned with the X-ray power set at $45 \mathrm{kVp}$ and $200 \mu \mathrm{A}$ with an integration time of $200 \mathrm{~ms}$. For each section, 117 slices were acquired at a resolution of $4.9 \mu \mathrm{m} /$ pixel. Output images were processed with the Fiji software [38]: image stacks, comprising of 117 slices, were converted to an average intensity Z-projection image with auto-adjusted brightness and contrast.

\section{In situ immunolabeling}

A single tiller cut above the rhizome was collected at the peak biomass harvest. Sampling uniformity across eight miscanthus genotypes, with varying phenotypes, was achieved by collecting leaf and stem samples from the internode located halfway through the length defined between the uppermost full-grown ligule and the base of the tiller. Smaller sections $(1 \mathrm{~mm}-5 \mathrm{~mm})$ were cut from the middle portion of the leaf blade and from the middle of the internode. Subsequent steps for tissue fixation, processing and epitope immunolabeling were performed as previously described [23]. Negative immunological controls (Additional file 2: D) consisted of treating sections following this same procedure, but using primary mAbs which do not bind epitopes in the tissues [39]. For certain mAbs known to only bind to de-esterified forms of the epitopes, sections were subjected to a base treatment (BT) with $0.1 \mathrm{M} \mathrm{KOH} \mathrm{(1} \mathrm{h} \mathrm{followed} \mathrm{by} \mathrm{three} \mathrm{washes}$ with deionised $\mathrm{H}_{2} \mathrm{O}$ ), before blocking and $\mathrm{mAb}$ application. Microscopic inspection was performed using an Eclipse 80i microscope (Nikon Inc., Melville, New York, USA) equipped with epifluorescence optics. At least three micrographs for a given $\mathrm{mAb}$ were captured at the same exposure time with a Nikon DS-Ril camera head using NIS-Elements Basic Research software (Nikon).
Additional file 2 contains the full immunolabeling study using $22 \mathrm{mAbs}$.

\section{Results and discussion \\ Miscanthus cell wall and enzymatic hydrolysis}

We used an enzyme-mediated approach to determine the amenability to deconstruction of CWM from leaf and stem biomass from $M$. sinensis, $M$. sacchariflorus and two $M . \times$ giganteus genotypes. The hydrolytic mixture contained a broad spectrum of cellulolytic enzyme activities, including various cellobiohydrolases, and endo$(1 \rightarrow 4)$ - $\beta$-glucanases; of which, some have been reported to also have xylanase activity $[40,41]$. The CWM was not pretreated before enzymatic hydrolysis, to avoid minimising differences in recalcitrance between samples, and thus assess non-attenuated impacts of cell wall features on recalcitrance.

In mature miscanthus tissues (peak biomass and senesced stages), saccharification efficiencies from leaf biomass ranged between 12.4 and $23.2 \mathrm{GlcE}$ (\% of total glucose extracted), 2.7-8.6 XylE (\% of total xylose extracted) and 2.4-8.7 AraE (\% of total arabinose extracted). For stems, the values were 9.8-28.0 GlcE, 7.318.3 XylE and 3.5-14.0 AraE (Additional file 3). ANOVA revealed that the genotype, organ and development stage factors had significant effects on the extractability of glucose, xylose and arabinose $(P<0.05$; Additional file 4). GlcE is typically higher in leaf biomass, whereas XylE and AraE tend to be higher in stems. However, for these three monosaccharides, saccharification efficiency generally decreases as plants mature (Additional file 3). Notwithstanding these overall trends in the extractability of glucose, xylose and arabinose, not all genotypes showed similar behaviours, suggesting genotype-specific responses to enzymatic hydrolysis.

Lignin, ferulic (FA) and $p$-coumaric ( $p \mathrm{CA}$ ) acids, as well as the monosaccharides glucose, xylose and arabinose, that constitute cellulose, arabinoxylans (AX) and mixedlinkage $1 \rightarrow 3,1 \rightarrow 4$ - $\beta$-glucan (MLG), are, respectively, the main components of the phenolic and carbohydrate fractions of miscanthus CWM [42, 43]. Additionally, substitution by $O$-acetyl groups, which in grass cell walls occurs primarily on AX, can affect structural integrity [44-47], namely at the level of xylan-cellulose interactions [48-50]. All these cell wall components are linked among themselves and to others, forming intertwined networks of polymers, which confer the cell wall with physiological, mechanical and chemical integrity [46, 51-53].

A previously reported reference glycan profile for miscanthus cell wall showed that certain portions of the glycome are particularly heterogeneous between different miscanthus genotypes [23]. For a more focused study 
of these heterogeneous regions, we chose seven glycandirected mAbs: CCRC-M87-galactosylated xyloglucan [30]; CCRC-M154-arabinosylated xylans [31]; CCRCM144-4-O-methyl glucuronic acid (Me-GlcA)-substituted xylans [31]; CCRC-M137-unmodified xylan backbone, DP $\geq 4$ [31]; BG1-MLG [32]; CCRC-M7arabinosylated $(1 \rightarrow 6)-\beta$-D-galactan epitopes found in AGPs and RG-I [33, 34]; CCRC-M38-fully unesterified homogalacturonan backbone [28].

\section{Genotypic variation of tissue organisation and biomass quality}

Representative images acquired by X-ray $\mu \mathrm{CT}$ of senesced miscanthus stem sections showed clear anatomical variation between different genotypes (Fig. 1). For instance, gig01 and hyb03 are characterised by the presence of vascular bundles in the pith area, whereas in the M. sinensis genotypes and in sac01, these are absent and the pith has disintegrated to form a hollow stem. Moreover, gig01 and hyb03 have similar cross-sectional areas, double that of $\sin 09$ and $\sin 13$ and three times that of $\sin 11$ and $\operatorname{sac} 01$. The area for $\sin 15$ cross sections was $\sim 90 \%$ of those of the $M . \times$ giganteus genotypes. There is also variation in the number of vascular bundles per unit area; this measure being highest for $\sin 15$ followed by gig 01 and hyb03 with the lowest value for sac01.
The data derived from determining the relative abundances of the seven most discriminant glycan epitopes detected by the above-mentioned mAbs, and of glucose, xylose, arabinose, lignin, FA, $p \mathrm{CA}$ and acetate, have allowed to pinpoint desirable and undesirable traits in the miscanthus lignocellulosic crop for optimal saccharification. Hierarchical clustering, employing all these cell wall traits, provided better understanding of how the miscanthus genotypes differ from each other (Fig. 2). The resulting dendrogram shows that the main clustering between the different miscanthus genotypes caused the separation of $M$. sinensis $(\sin 08, \sin 09, \sin 11, \sin 13, \sin 15)$ from M. $\times$ giganteus (gig01, hyb03) and M. sacchariflorus (sac01). The formation of these two main groups clearly suggests that biomass from $M$. sinensis is compositionally distinct from that of other genotypes included in this study. As a trend, M. $\times$ giganteus and $M$. sacchariflorus genotypes have higher relative abundances of ferulic and $p$-coumaric acids, glucose and xylose, except for their senesced leaf biomass, where relative content in these monosaccharides is more uniform between the two clusters. Most of the arabinose in grass cell walls is found bound to xylan backbones, forming arabinoxylan (AX), which is the most abundant arabinosylated polysaccharide in miscanthus cell wall [23, 54]. Arabinose/xylose ratios are frequently used as indicators of the degree of
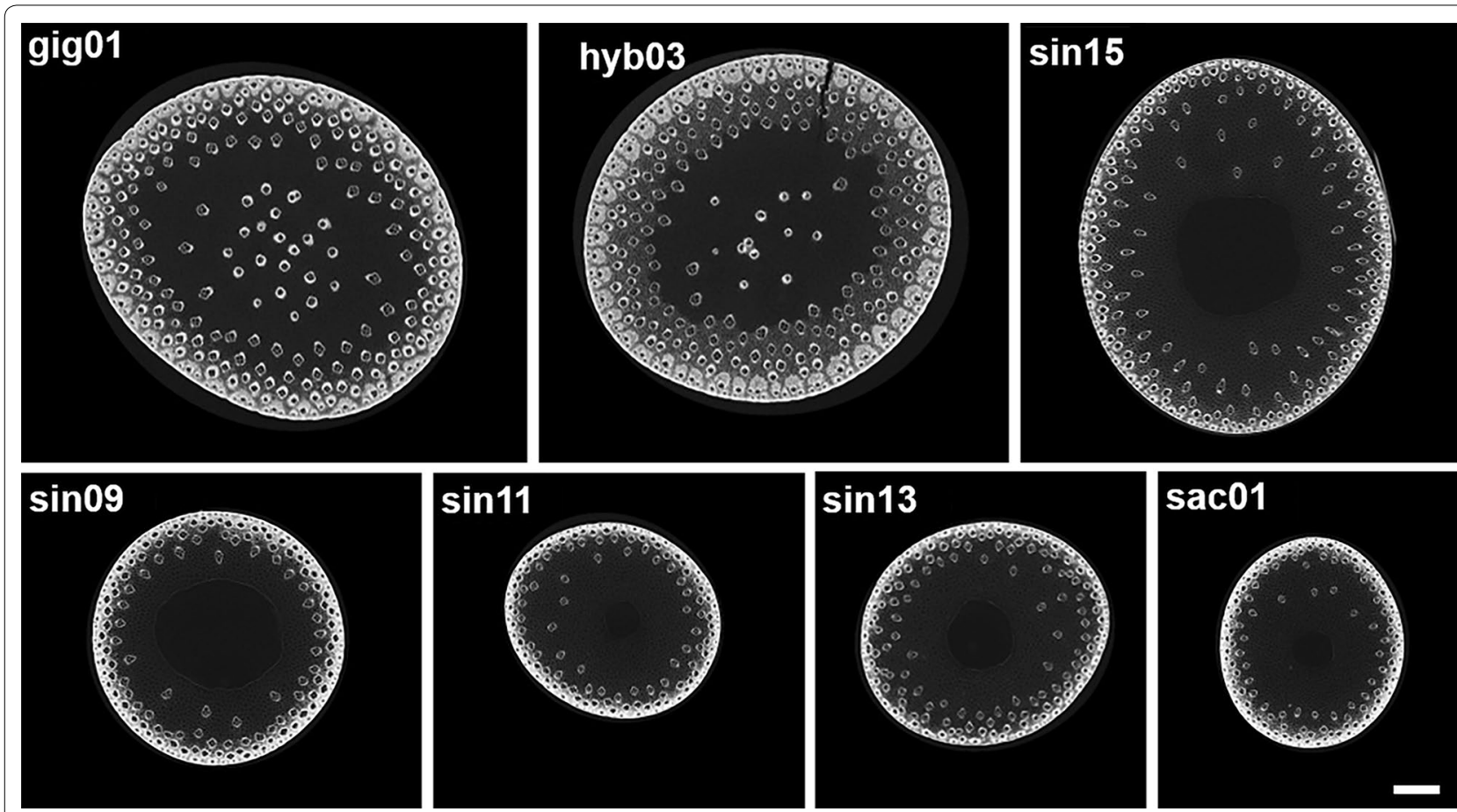

Fig. $1 \mu C T$ scanning of senesced stem midsections from 7 of the 8 miscanthus genotypes used in this study. These data show clear differences in the stem diameter and anatomical organisation of the different genotypes, in particular for vascular bundle number and distribution, and non-hollow stems in the two M. × giganteus genotypes (gig01 and hyb03). Images are Z-projections of 117 slices. Scale bar: 1 mm 

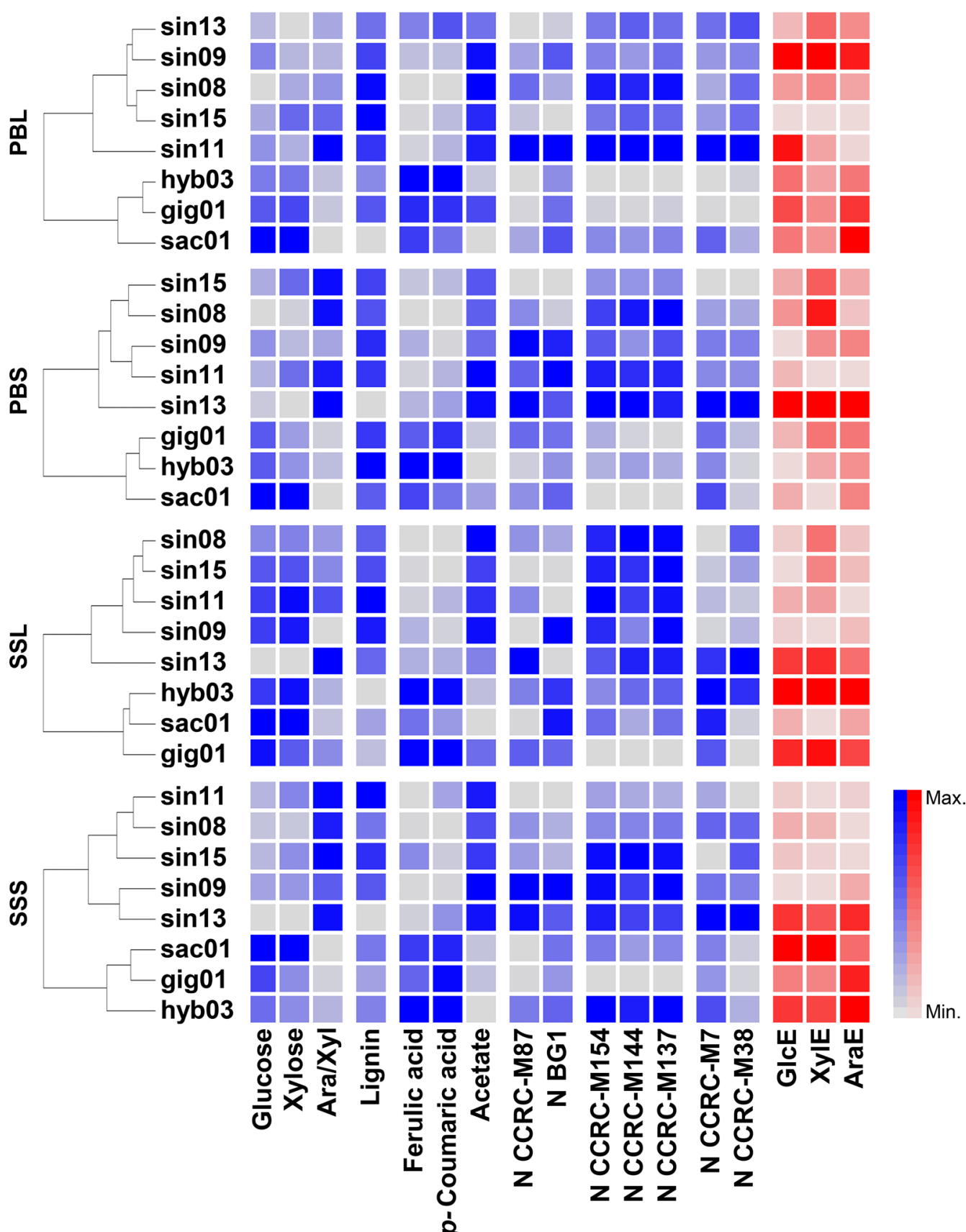

Fig. 2 Clustering of 8 miscanthus genotypes, based on the cell wall traits from their leaves (L) and stems (S), harvested at peak biomass (PB) and senesced (SS) stages. For a given dendrogram, the colour intensities within each row of the adjacent heatmap, represent relative abundances of corresponding cell wall traits in that genotype. Shades of red represent saccharification efficiency indices: the percentages of total glucose (GlcE), xylose (XyIE) and arabinose (AraE) released upon enzymatic saccharification. Cell wall compositional features are represented in shades of blue. Ara/Xyl, is the ratio of arabinose to xylose determined in the cell wall material (CWM). N designates the normalised value representing the total epitope abundance (OD/g of CWM) for specific mAbs: xyloglucans (CCRC-M87, galactosylated xyloglucan), glucan (BG1, MLG), xylans (CCRC-M137; CCRC-M144; CCRC-M154) and pectins (CCRC-M7, RG-I/AG; CCRC-M38, homogalacturonan backbone). Only cell wall composition data (blue), and not the three saccharification-related variables (red), were considered for genotype classification, which was performed via agglomerative hierarchical clustering, using the 'hclust'R-function. More detail regarding the glycan-directed mAb classes is available in Additional file 1. Genotype $\sin 13$ often showed compositional traits misaligned with the remaining $M$. sinensis genotypes, as its biomass was typically made up of softer tissues than those of other genotypes. This is likely to be caused by phenotypical properties of $\sin 13$ at the level of an intrinsic and distinct developmental gradient that occurs within the plant anatomy 
xylan arabinosylation [55], and in $M$. sinensis biomass, these ratios tend to be higher than in $M . \times$ giganteus and $M$. sacchariflorus genotypes. Similarly, the relative abundance of lignin, acetate and of xylan epitopes (probed by CCRC-M137, CCRC-M144 and CCRC-M154) are typically higher in $M$. sinensis.

Only cell wall compositional and structural traits were considered for the clustering analysis. Yet, by analysing the associated saccharification efficiency indices (GlcE, XylE and AraE), represented in shades of red (Fig. 2), we see that senesced non-sinensis genotypes, hyb03 and gig01, tend to display relatively higher saccharification efficiencies. To obtain a deeper understanding of how varying compositional and structural cell wall features impact on saccharification, four genotypes were chosen to include two representatives from each group arising from the clustering analysis: hyb03, sac01, sin08 and $\sin 11$.

Previously determined information about the most variable portions of miscanthus cell wall glycome [23] was used to reduce the number of employed mAbs to 21 . By only including these most heterogeneous portions of the glycome, the analysis of individual genotypes became more objective and targeted. Glycome profiling heatmaps (Fig. 3) and in situ immunolabeling of cell wall glycan epitopes (Fig. 4; Table 1) show further detail of the binding intensity of these glycan-directed mAbs. For all genotypes, the higher amount of carbohydrate was extracted with $1 \mathrm{M} \mathrm{KOH}$ during the sequential extraction, followed by $4 \mathrm{M} \mathrm{KOH}$ (Additional file 5). Epitopes in xyloglucan polymers, probed with CCRC-M87 showed strong labelling of the phloem, in most genotypes, except for hyb03. MLG immunolabeling with BG1 was visible throughout the tissue sections, particularly in vascular bundles and in bundle sheaths, including the cell wall of lignified sclerenchyma tissues of $M$. sinensis genotypes. Coincidentally, during glycome profiling, the binding intensity of BG1 was markedly higher in the chlorite extract from leaves of $\sin 08$ and $\sin 11$, which suggests higher abundances of lignin-associated MLG in these genotypes (Fig. 3). Probing of xylan epitopes showed distinct labelling patterns, according to the $\mathrm{mAb}$ and to the genotype under study, indicating xylan heterogeneity. Ester-linked substituents can be an important aspect of these differences, as suggested by employing CCRC-M144 together with a $0.1 \mathrm{M}$ $\mathrm{KOH}$ treatment to cleave ester bonds (Fig. 4; Additional file 2: D, E). Ester-linked acetyl and hydroxycinnamoyl substituents are known to cause significant differences in biomass saccharification, and indeed, we saw that $M$. sinensis genotypes have relatively lower proportions of HCAs (Fig. 2). Further evidence of the distinct fine structure properties between the genotypes comes from probing homogalacturonan epitopes with CCRC-M38, with and without the $0.1 \mathrm{M} \mathrm{KOH}$ base treatment (Fig. 4), as the increase in labelling after alkaline saponification was more obvious in $M$. sinensis genotypes, particularly for stem sections.

The relevance of slight differences in glycan epitope structure and distribution may be associated with their involvement in providing structural reinforcement, or protection against external attack. Examples of this are epitopes occurring in xyloglucans (CCRC-M87) and in xylans (CCRC-M137 and CCRC-M144), which occur in corners of intercellular spaces and on the walls of the epidermis and cuticle (Fig. 4). These epitopes are only substantially removed from the cell wall with the harshest extractants, $1 \mathrm{M}$ or $4 \mathrm{M} \mathrm{KOH}$ (Fig. 3). It is possible that these epitopes are integrated in glycans that enhance tissue resistance to deconstruction. Thus, higher abundances of such epitopes may result in higher recalcitrance of cell wall biomass fractions containing such polysaccharide structures.

\section{Associations between cell wall traits and their influence on recalcitrance}

A correlation matrix was constructed with the aim of assessing how the three saccharification efficiency indices (GlcE, XylE and AraE) are associated with cell wall traits. In stem and in leaf biomass, these indices are significantly and positively correlated to each other (Fig. 5). Nevertheless, in different types of biomass, distinct sets of factors can affect saccharification efficiency. Specifically, saccharification of leaves is influenced by a distinct and more complex set of cell wall traits compared to stems.

None of the saccharification indices is significantly correlated with total glucose content in the cell wall. However, GlcE from leaves is significantly and positively correlated with the relative abundances of epitopes recognised by CCRC-M87 $(r=0.50, P<0.05)$ and BG1 $(r=0.36, P<0.05)$, which, respectively, occur in xyloglucan and in MLG polymers. By contrast, negative correlations occur between GlcE and XylE and total xylose content in both organs, while in leaves, AraE is negatively associated with the abundance of xylan-directed mAbs (CCRC-M137, CCRC-M144 and CCRC-M154) (Fig. 5; Additional file 6: A). Glucose in grass cell walls primarily derives from cellulose, therefore our data suggest that higher amounts of cellulose may be detrimental for saccharification efficiency. Indeed, reports have suggested that polysaccharides tightly associated with cellulose are shielded from enzymatic attack by AX and MLG [56], and higher amounts of cellulose may present more structured obstacles to enzyme action [57]. CCRC-M87 and BG1 epitopes are more abundant in leaf than in stem biomass (Additional file 3), and as the employed enzymatic cocktail has primarily cellulase and $\beta$-glucosidase 


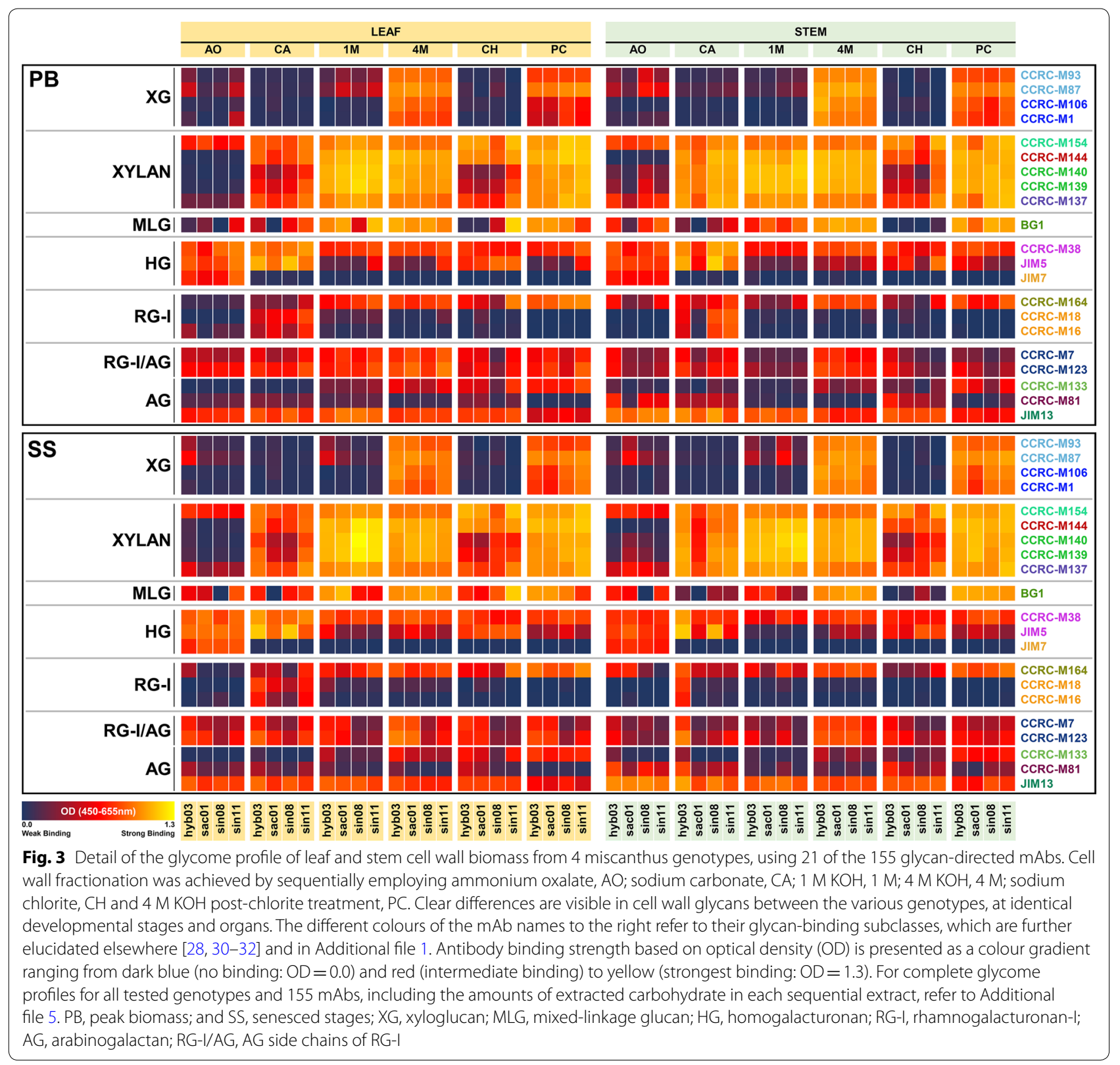

(See figure on next page.)

Fig. 4 Immunofluorescent labelling of cell wall glycan epitopes in transverse sections from leaves and stems from 4 miscanthus genotypes. Immunolabeling studies were preceded by microscopic inspection of sections stained with toluidine blue to characterise their histological complexity. Monoclonal antibodies (mAbs) used in the study are directed at xyloglucan, MLG, xylan and pectin epitopes. More information on these and other mAbs is provided in Table 1 and in Additional file 1. A base treatment (BT) with $0.1 \mathrm{M} \mathrm{KOH}$, which removed ester-linked substituents from the cell wall, was used together with CCRC-M144 and CCRC-M38. The non-base-treated control of CCRC-M155, as well as the complete immunolabeling study (total of 22 glycan-directed mAbs and 8 genotypes), is available in Additional file 2. ae, abaxial surface epidermis; bs, bundle sheath; on, organelle; gt, parenchymatous ground tissue; is, intercellular space; mf, mesophyll cells; mx, metaxylem; ph, phloem; px, protoxylem; sf, sclerenchyma fibres; st, stomatal complex; xp, xylem parenchyma. Scale bars: $100 \mu \mathrm{m}$ 

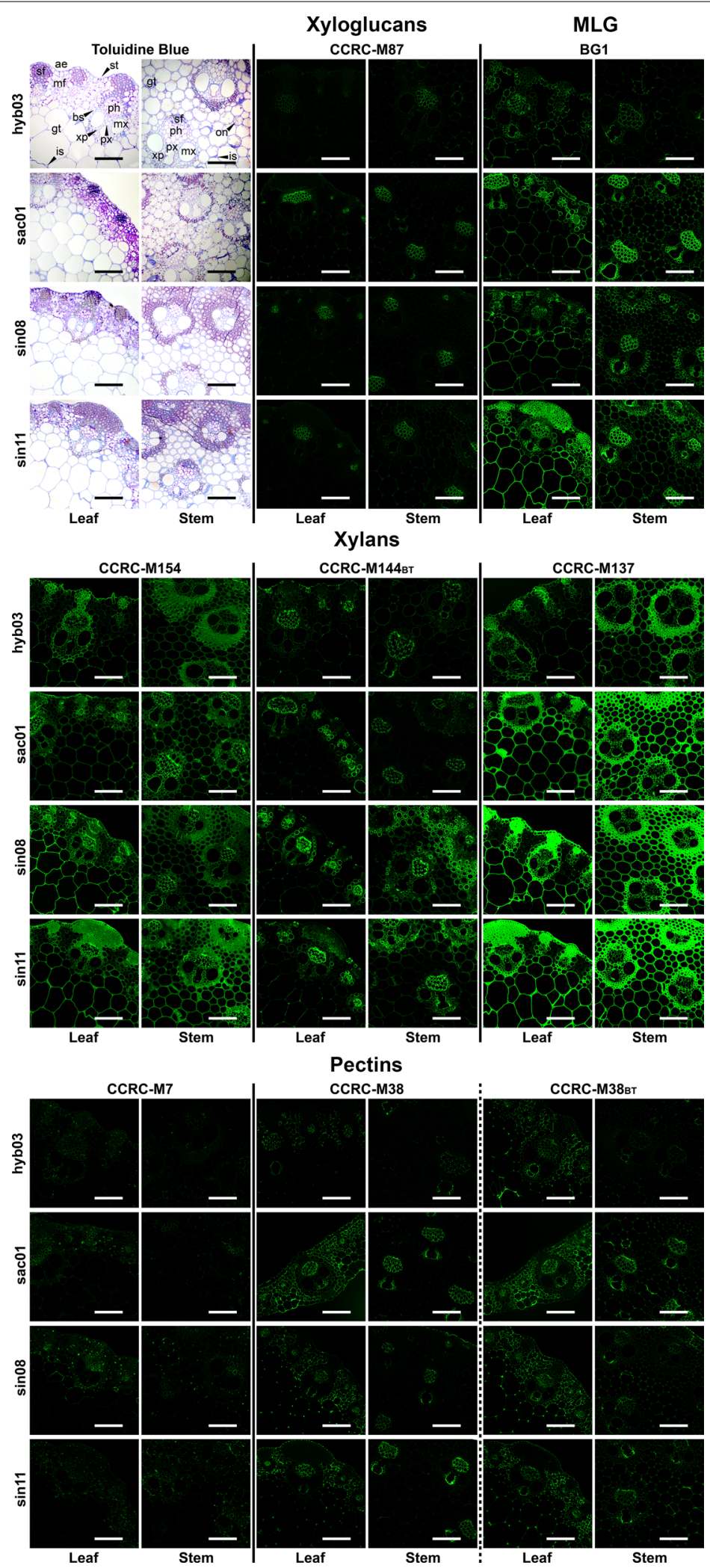
Table 1 Cell wall glycan-directed monoclonal antibodies (mAbs) used in the study of in situ immunolabeling of miscanthus leaf and stem tissues

\begin{tabular}{ll}
\hline $\mathbf{m A b}$ & Epitope \\
\hline CCRC-M87 & Galactosylated xyloglucan [30] \\
BG1 & Mixed-linkage $(1 \rightarrow 3,1 \rightarrow 4)$ - $\beta$-glucan [32] \\
CCRC-M154 & Arabinosylated xylan [31] \\
CCRC-M144 ${ }^{\text {BT }}$ & Me-GlcA substituted xylan [28, 31] \\
CCRC-M137 & Unmodified xylan backbone (DP $\geq 4)[31]$ \\
CCRC-M7 & Arabinosylated $(1 \rightarrow 6)-\beta$-D-galactan found in \\
CCRC-M38 & AGPs and RG-I $[33,34]$ \\
\hline
\end{tabular}

Further information on the mAbs used here may be found in Additional file 1

BT Also used in combination with a $0.1 \mathrm{M} \mathrm{KOH}$ base treatment of the sections before immunolabeling

activity, higher proportions of non-cellulosic glucans in leaves may allow for more efficient hydrolysis of the cell wall. Conversely, as the enzymatic cocktail only has minimal xylanase activity, the coating of cellulose microfibrils with xylans may be one reason for negative correlations between saccharification, and xylose and xylan epitope abundances. Moreover, it is known that lower hemicellulose contents are associated with more effective cellulose deconstruction [58], and that several xylooligomers may inhibit enzymatic hydrolysis of glucan and xylan [59, 60]. Arabinose/xylose ratios are significantly and positively correlated with GlcE in leaves $(r=0.36, P<0.05)$. In stems, these ratios are typically lower (Additional file 3 ). Highly substituted AXs are more abundant in the primary cell wall, while more linear xylans are often associated with lignification and secondary cell walls [61]. Experimentally, high alkali concentrations are needed for the extraction of unsubstituted xylans [53], and higher xylan arabinosylation enhances enzymatic digestibility [62]. Furthermore, the abundance of arabinogalactan epitopes probed by CCRC-M7 is significantly and positively correlated with saccharification efficiencies in both studied miscanthus organs, albeit more predominantly in leaves (Fig. 5). Similarly, in sodium carbonate and $4 \mathrm{M} \mathrm{KOH}$ extracts from leaf biomass, the abundances of CCRC-M144 and CCRC-M154 epitopes are significantly and positively correlated with GlcE and XylE (Additional file 6: C). By contrast, in $1 \mathrm{M} \mathrm{KOH}$ extracts from leaves, the correlation between the abundances of CCRC-M144 and CCRC-M154 epitopes is negative (Additional file 6: C). Altogether, these observations strongly suggest that saccharification may benefit from higher degrees of xylan glycosyl modification. However, this association is likely to be more complex than a direct association between xylan ornamentation and saccharification efficiency. Indeed, the compositional and structural nature of the parent glycoforms must be considered for optimal lignocellulose biorefining. Particularly, as we observed that acetyl and hydroxycinnamoyl ornamentation are distinctly correlated to saccharification efficiency. Acetyl and the hydroxycinnamoyl ( $p$ CA and FA) are typically the most abundant ester-linked xylan substituents in miscanthus cell wall [63-66]. Significant and negative correlations were seen between determined acetate content and saccharification efficiency of glucose $(r=-0.54$, $P<0.05)$ and arabinose $(r=-0.58, P<0.05)$ in leaf biomass (Fig. 5; Additional file 6: A). It is likely that acetylation of glycosyl residues of polysaccharides creates steric hindrance for binding of many hydrolytic enzymes, which limits the extent of hydrolysis [45, 47, 67]. Furthermore, it has been reported that the pattern of xylan acetylation may influence how xylan interacts with cellulose in secondary cell walls $[50,68]$, and that chemical deacetylation of cell wall biomass substantially improves saccharification [69-72].

In grass cell walls, FA is typically found ester-linked to arabinosyl substituents of AX [44, 73, 74], where it may simultaneously ether-link to lignin monomers $[65,75]$, or even form dimers and other oligomers, which crosslink carbohydrate chains $[48,52]$. Here, we have determined the amounts of ester-linked monomeric FA, which are significantly and positively correlated with the saccharification efficiency of glucose $(r=0.45, P<0.05)$ and arabinose $(r=0.73, P<0.05)$ in leaf biomass and of arabinose $(r=0.37, P<0.05)$ in stems (Fig. 5; Additional file 6: A, B). Ester-linked FA monomers may be oxidatively coupled, forming dimers and oligomers which crosslink AX polymers and produce tighter molecular structures in grasses [44, 65, 76, 77]. Thus, it may be hypothesised that in cell walls where higher abundances of monomeric ester-linked FA occur, lower proportions of these monomers have yet been coupled, leading to less recalcitrant structures, than those where FA-mediated cross-linking is more abundant. Hence providing an explanation for the positive correlations observed between ester-linked FA monomers and the saccharification indicators.

The abundance of MLG epitopes probed by BG1 in sodium chlorite extracts from leaves is negatively correlated with GlcE $(r=-0.43, P<0.05)$ and XylE $(r=-0.50$, $P<0.05$ ) (Additional file 6: $\mathrm{C}$ ). However, in $4 \mathrm{M} \mathrm{KOH}$ extracts from leaves, BG1 epitope abundance appears to be beneficial to GlcE $(r=0.65, P<0.05)$ and XylE $(r=0.71, P<0.05)$. As sodium chlorite removes lignin from the cell wall, glycan epitopes identified in sodium chlorite extracts, including those bound by BG1, may belong to MLG populations somehow associated with lignin. This suggests a structural role for MLG, and 


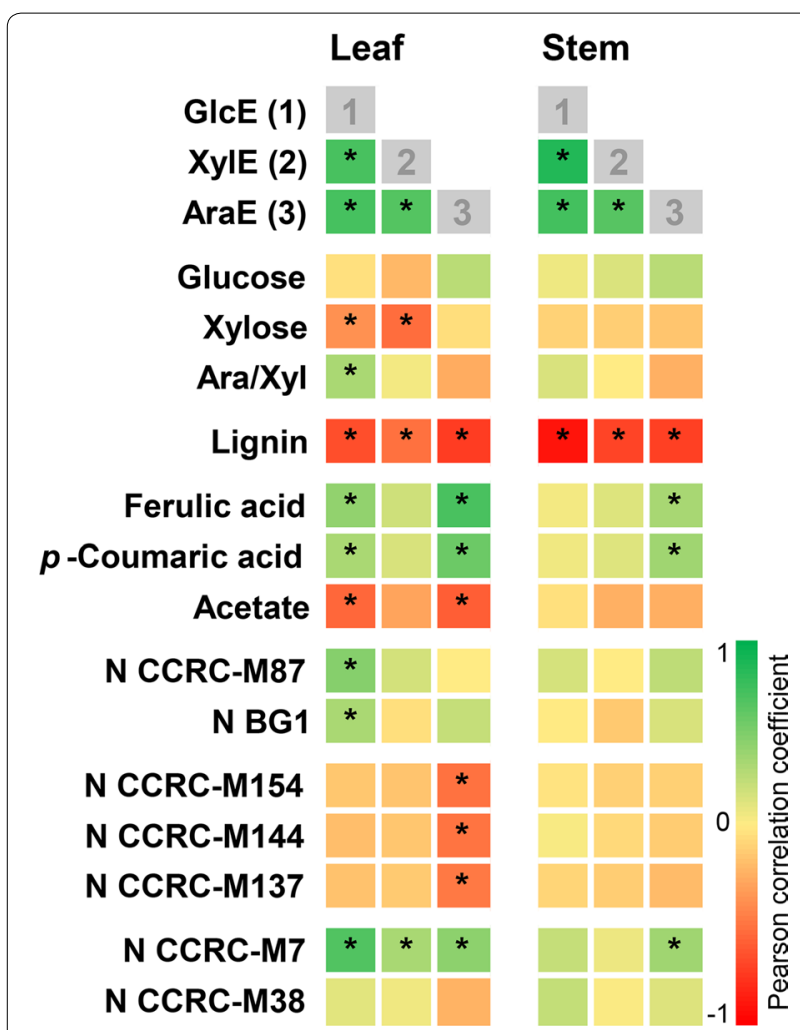

Fig. 5 Correlation matrix between measured cell wall compositional features and enzymatic saccharification efficiency of glucose (GlcE), xylose (Xy|E), arabinose (AraE), in miscanthus biomass harvested at the peak biomass and senesced stages. Values for GlcE, XylE and AraE consist of the percentages of the total content of the corresponding monosaccharide that exists in the cell wall (\% total glucose; \% total xylose; \% total arabinose), released upon enzymatic saccharification. Pearson correlation coefficients are presented as a colour gradient ranging from red to green. Statistically significant correlations $(P \leq 0.05, n=32)$ are identified with $a^{\prime * \prime}$. For the eight miscanthus genotypes, GlcE, XylE, AraE, Glucose, xylose, lignin, ester-linked ferulic and $p$-coumaric acids and acetate were measured as \% cell wall material (CWM). Ara/Xyl is the ratio of arabinose to xylose determined in the CWM. N designates the normalised value representing the total epitope abundance (OD/g of CWM) for specific mAbs: xyloglucans (CCRC-M87, galactosylated xyloglucan), glucan (BG1, MLG), xylans (CCRC-M137; CCRC-M144; CCRC-M154) and pectins (CCRC-M7, RG-I) AG; CCRC-M38, homogalacturonan backbone). More detail regarding the glycan-directed $\mathrm{mAb}$ classes is available in Additional file 1. The full correlation matrix and associated $P$ values are shown in Additional file 6

indeed it has been reported that the presence of MLG in mature tissues provides cell wall strengthening [78-80]. In fact, in rice it has been reported that MLG depletion is accompanied by a lignin content increase, likely as compensation for the lack of MLG [79].

Pectin epitope abundances probed by CCRC-M7 and CCRC-M38 did not show any significant negative correlation with saccharification indices in the extracts obtained with the less stringent extractants. Instead, for both mAbs, epitope abundances in $4 \mathrm{M} \mathrm{KOH}$ extracts from leaf cell wall are significantly and positively correlated with GlcE $(r>0.74, P<0.05)$ and XylE $(r>0.58$, $P<0.05)$. However, in switchgrass, rice and poplar, biomass yields and sugar release were improved in plants engineered to reduce expression of a pectin biosynthesis gene, presumably due to reduced homogalacturonan and RG-II cross-linking in the cell wall [81]. Therefore, the contribution of pectins to cell wall assembly and biomass conversion should not be considered a secondary factor when developing miscanthus varieties for optimised bioconversion.

The abundance of epitopes released after delignification (4 M KOH PC) generally have negative Pearson coefficients, demonstrating negative associations with saccharification performance (despite not statistically significant; Additional file 6: C). In $1 \mathrm{M} \mathrm{KOH}$ extracts, xylan epitopes CCRC-137, CCRC-M144 and CCRCM154 are negatively correlated with GlcE $(r<-0.52$, $P<0.05)$ and XylE $(r<-0.45, P<0.05)$ in leaves. However, in $4 \mathrm{M} \mathrm{KOH}$ extracts, epitope abundances for CCRC-137, CCRC-M144, CCRC-M154, CCRC-M87 and BG1 are positively correlated with GlcE $(r>0.65$, $P<0.05)$ and XylE $(r>0.70, P<0.05)$ (Additional file 6: $C)$. This supports the idea that a certain epitope probed by the same mAb in different extracts can occur in distinct glycoforms that exist in the cell wall for each polymer type, and are capable of conferring varying degrees of recalcitrance. Indeed, reports have suggested that some glycans may occur in the cell wall simultaneously as polysaccharides and proteoglycans, and that a given kind of matrix polysaccharide could encompass various distinctive polymers, each with unique roles in the primary or secondary cell walls of different cell types [81-83]. Altogether, these observations highlight the high relevance of the cell wall glycome for leaf biomass saccharification.

In stems, lignin is the only cell wall feature negatively affecting GlcE and XylE (Fig. 5). This negative effect on saccharification is mainly due to lignin-carbohydrate complexes which form barriers and cause nonproductive binding with hydrolytic enzymes, limiting accessibility to cell wall core polysaccharides and inhibiting hydrolysis [84]. However, even though the negative effects of lignin on recalcitrance are well known, the structural complexity of lignin confuses our understanding of underlying relations between lignin structure and recalcitrance $[11,85]$. Indeed, lignin structure, instead of lignin content, is what seems to affect recalcitrance the most, as demonstrated by improved digestibility in biomass containing lignins with more labile linkages [86]. 


\section{Saccharification performances and biomass quality}

To elucidate which cell wall features are desirable for optimal saccharification, we followed a categorical approach to discern between biomasses displaying "good" or "bad" conversion performances. However, the rankings seen for GlcE did not coincide with those of XylE. Furthermore, a given genotype that ranked high or low in leaf biomass did not necessarily have a comparable saccharification performance in stem. This lack of agreement between leaf and stem indicates that distinct mechanisms dictate recalcitrance to sugar release, depending on the sugar (glucose or xylose) and plant organ (leaf or stem). Leaf and stem CWM samples were therefore binarily classified as high or low yielders based on the percentage of glucose or xylose released upon enzymatic saccharification, with the median of all saccharification efficiency values representing the threshold dividing the two classes (Fig. 6).

Paired-sample t-tests (Additional file 7), in combination with previously determined correlation coefficients (Fig. 5), allowed the determination of cell wall traits significantly different between "good" and "bad" performers, while simultaneously assessing the impact of these differences on saccharification efficiency (Fig. 7). High saccharification efficiencies from leaf biomass seem to depend on more features than those affecting stem biomass. This is in agreement with our previous reports, suggesting that leaf and stem cell wall assembly is regulated by distinct mechanisms, which are translated into very distinct saccharification performances [22-24]. Lignin and acetate are features negatively affecting saccharification and are significantly different between the high and low performing classes. Particularly for GlcE, the abundance of xylan epitopes is also a negative discriminant feature affecting enzymatic hydrolysis. In stem biomass, acetate and lignin contents are negative discriminant features affecting XylE, but lignin is the only cell wall trait that is significantly different between the high and low glucose yielders (Fig. 7). Despite this, we cannot presume that lignin is the only recalcitrance-enhancing agent in stem biomass. Indeed, in switchgrass, although lignin content is generally negatively correlated with saccharification, it is not the sole contributor to recalcitrance across diverse anatomical features [87].

\section{Desirable cell wall traits for ideotype breeding}

To improve lignocellulosic crop performance, the whole plant is the final object of research. Plant growth depends on potentially resource-competing, morphological, physiological and biochemical processes, which are often hard to consider as a whole when trying to decipher a desirable phenotype for improved performance. The proposal of such phenotypes consists of the ideotype approach [88,
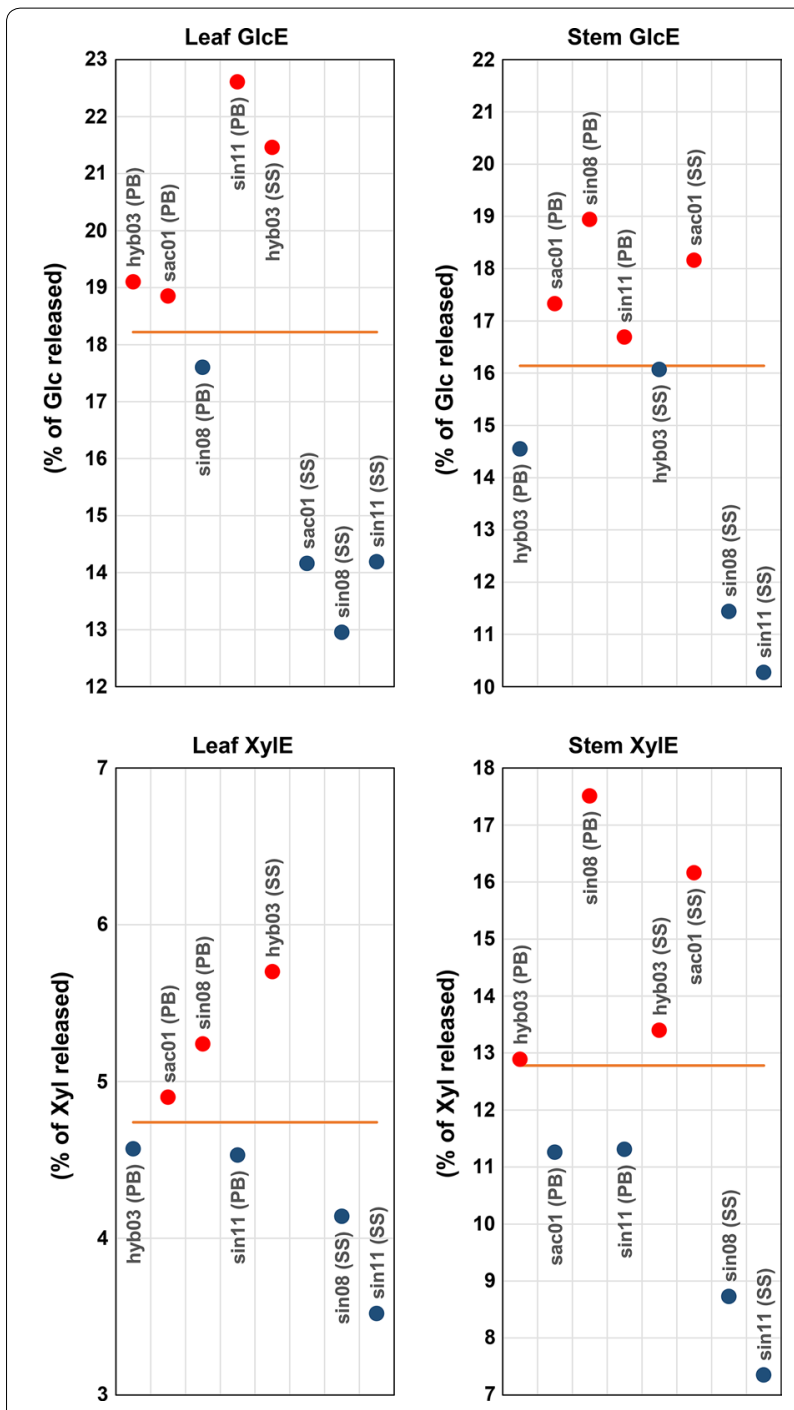

Fig. 6 High (red) and low (blue) yielders of glucose (GlcE) and xylose (XyIE), upon enzymatic saccharification. Values in the $y$-axes are the percentages of the total content of the corresponding monosaccharide that exists in the cell wall (\% total glucose; \% total xylose). Only the subgroup of 4 miscanthus genotypes is shown. However, the orange horizontal line represents the median of the values obtained for the 8 original miscanthus genotypes. For further details, see Additional file 7. PB, peak biomass; SS, senesced stage

89], which in the context of lignocellulosic crops should consist of a cultivar that performs in a predictable manner, leading to optimal biorefining conversion and lifecycle assessment performances, while maintaining plant integrity. The discriminant cell wall traits between high and low saccharification efficiency performers (Fig. 7) helped us define which biomass traits are desirable in a miscanthus ideotype for biorefining.

Lignin is a recalcitrance-enhancing factor, in all types of miscanthus biomass tested. However, the negative 


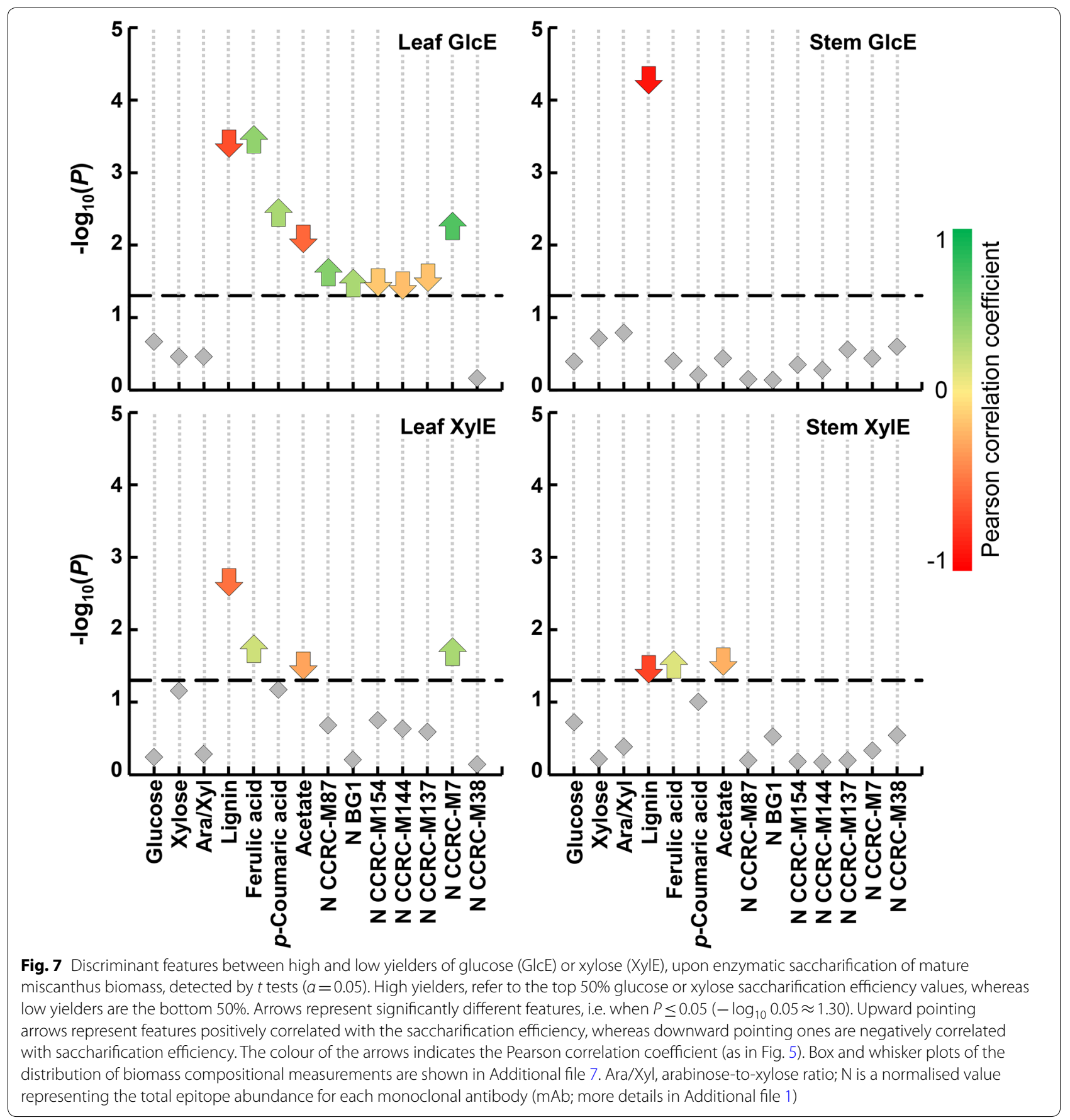

correlation between lignin and saccharification efficiency is likely a consequence of lignin molecular structure instead of its overall content. Lignification is a flexible process [90], with the potential of constructing lignocellulosic crops with less recalcitrant lignins. Approaches to achieve this can vary from selecting plants enriched in syringyl units [10], which form more easily cleaved $\beta-O-4$ inter-unit linkages, to the generation of plants that incorporate HCA-related (FA and $p \mathrm{CA}$ ) conjugates into lignin [86, 91], yielding lignin with elevated ester linkages amenable to mild alkaline depolymerisation. Numerous economic benefits exist for maintaining normal in planta lignin levels, while reducing its recalcitrance, particularly as novel conversion pathways emerge for lignin utilisation [11]. Furthermore, refinement of biomass downstream processing has enhanced lignin recovery, which, 
coupled with genetic engineering, may enable new uses for lignin [10, 92]. Additionally, a recent breakthrough process for lignin depolymerisation may improve the yields of low molecular weight aromatic monomers with high potential industrial value [12]. These technical advances may eventually lead to cost-effective utilisation of lignin-derived chemicals for parallel biomaterial production, which in turn will add value to lignocellulosic biomass applications, and thus enhance the economic viability of lignocellulosic biofuels.

Previous studies have reported cell wall composition and bioconversion traits in miscanthus aimed at improving biomass quality and facilitating its use as feedstock for biofuel production [93]. However, cell wall acetylation is often not considered as a trait with a substantial effect on cell wall recalcitrance. Here, we demonstrate that acetylation has a negative influence on cell wall saccharification and is a discriminant feature between high and low yielders (Fig. 7). In grass primary walls, most acetylation occurs in AX [47], where it partly contributes to the interaction with cellulose and lignin [50, 68, 94, 95]. Deficiencies in Arabidopsis mutants with reduced acetylation suggested a fundamental role of acetylation in cell wall mechanical integrity $[96,97]$. Ultimately, acetate can simultaneously inhibit saccharification and fermentation $[98,99]$, by causing steric hindrance of hydrolytic enzymes [45, 47, 67], and by becoming toxic to fermenting microbes $[46,100]$. In agreement, aspen plants with reduced xylan acetylation showed $25 \%$ higher glucose saccharification yield compared with wild types [101]. Our current knowledge still does not allow inferences about the repercussions of merely reducing in planta cell wall acetylation on the viability and saccharification performance of a poalean lignocellulosic crop. Nonetheless, our data clearly show that acetylation is significantly correlated with the saccharification of miscanthus biomass, and its impact should be further addressed within crop improvement programmes.

Glucose content is higher in CWM from miscanthus stems than in leaves, but glucose determinations, and therefore cellulose content is not significantly correlated with saccharification efficiency (Fig. 5). The reason for these observations is not clear, but they do indicate complex relationships between glucose content and sugar extractability. Our findings corroborate the concept that alongside relative abundances, the structure of the cell wall and how polymers interconnect, must be considered for the improvement of lignocellulosic feedstocks such as miscanthus. Higher abundance of cellulose may in fact enhance recalcitrance, because of its crystalline nature $[11,102]$, and it has been reported that reduction of cellulose crystallinity results in more efficient cellulase action [103]. Therefore, breeding for miscanthus varieties with increased cellulose content may not necessarily lead to better saccharification performance.

The design of a miscanthus ideotype for biorefining should also consider the abundance of certain glycan epitopes, which based on their in situ location (Fig. 4), may be integrated in polysaccharide structures involved in providing structural reinforcement (e.g. corners of intercellular spaces), or protection against external attack (e.g. epidermal cells and cuticles). Higher abundances of such epitopes may be an indicator of higher recalcitrance of the polymers where they are included. Therefore, the study of glycan distribution may provide further insights into which glycan epitopes have more relevant effects on saccharification.

Leaves are mostly composed of mesophyll and large parenchymatous cells in the ground tissue, with typically thinner cell walls than in stems. It is likely that these structural features are more amenable to hydrolytic enzyme access, and thus sugar release. We have previously suggested that leaf-to-stem ratios may influence miscanthus biorefining performances [24]. Here, we also show that mean GlcE is higher in leaves than in stems (Additional file 3). Therefore, we argue that merely increasing overall biomass yields should not be the main strategy for lignocellulosic crop improvement, as high biomass producers may not always be the most costeffective varieties, and high carbohydrate content is not always synonymous with high saccharification efficiency. Thus, attempts to generate less recalcitrant plant varieties, namely by increasing leaf biomass proportions, even if at the cost of total biomass yield reductions, could be a worthy route to explore in plant breeding. Ultimately, it is likely that less recalcitrant biomass will allow substantial economic and resource savings in transport and in downstream biomass processing.

\section{Conclusions}

Our analysis of miscanthus biomass revealed that the cell wall makeup and biomass quality are significantly distinct between plant organs, groups of genotypes and species. We identified a set of cell wall variables, including molecular features that affect the fine structure of the cell wall, that are distinct between genotypes with high or low saccharification efficiency performances and can therefore be used as markers to help interrogate future datasets. Specifically in stems, lignin has a predominant effect on recalcitrance, and its modification may therefore have a beneficial impact on saccharification. In foliar biomass, the picture is more complex as cell wall traits related to the nature and ornamentation of matrix glycans have more determinant positive or negative effects on saccharification and hence may be targets to improve the biorefining potential of leaves. Organ-derived differences in 
cell wall deconstruction will have distinct impacts on biomass valorisation, especially when considering the variation in leaf and stem contribution to total biomass across different miscanthus genotypes [24]. Thus, the development of miscanthus varieties with modified leaf-to-stem ratios may in itself lead to biorefining improvements.

Novel biomass processing methodologies are being developed to produce added-value chemical commodities from hemicellulose sugars, for instance, by converting xylose into xylitol [104-106]. Reports have also shown that many phenols of interest for nutraceutical, cosmetic and pharmaceutical industries occur in miscanthus biomass $[107,108]$. This underlines the potential of miscanthus biomass valorisation through a cascading biorefining concept. Although miscanthus species are essentially undomesticated, in temperate climates they outperform many other $C_{4}$ crops [109]. Furthermore, there is huge potential of their genetic resources to be utilised for crop improvement [110]. The results obtained in this study reinforce the value of a detailed exploration of such genotypic diversity in cell wall-related molecular traits to define and refine markers that can be exploited for the development of miscanthus as a renewable biorefinery feedstock. Our findings promote the idea that a holistic outlook of the cell wall is indispensable to improve biomass quality. Hence, instead of defining a single miscanthus biorefining ideotype, the development of a collection of varieties, taking into account target products, provides a more realistic and valuable approach.

\section{Additional files}

Additional file 1. Listing of all plant cell wall glycan-directed monoclonal antibodies used in the glycome profiling screening.

Additional file 2. Full dataset of the immunofluorescent labelling study of glycan epitopes in transverse sections from miscanthus leaf and stem. The first panel refers to sections stained with toluidine blue.

Additional file 3. All measured values for the cell wall traits for each of eight miscanthus genotypes used in this study.

Additional file 4. ANOVA tables of results from enzymatic saccharification efficiency.

Additional file 5. Complete glycome profile of cell wall material from all samples used in this study.

Additional file 6. Correlation matrices between all measured cell wall compositional features and enzymatic saccharification efficiencies of glucose, xylose, arabinose.

Additional file 7. Box and whisker plots showing the distribution of biomass compositional measurements, and the $P$-values of $t$ tests used to discriminate between genotypes with high or low saccharification efficiency indices.

\section{Authors' contributions}

RC, AW and MB planned and designed the research. RC performed experiments and data analyses. Glycome profiling and immunohistochemistry was performed in collaboration with Dr Ronald Clay, UA and SP, under the supervision of $\mathrm{MH}$. The manuscript was produced by $\mathrm{RC}$, with critical feedback from MB. All the authors discussed the results and commented on the manuscript. All authors read and approved the final manuscript.

\section{Author details}

${ }^{1}$ Institute of Biological, Environmental and Rural Sciences, Aberystwyth University, Plas Gogerddan, Aberystwyth, Ceredigion SY23 3EE, UK. ${ }^{2}$ Complex Carbohydrate Research Center, University of Georgia, 315 Riverbend Rd., Athens, GA 30602-4712, USA. ${ }^{3}$ DOE-BioEnergy Science Center (BESC), Oak Ridge National Laboratory, Oak Ridge, TN 37831, USA. ${ }^{4}$ Present Address: Centre for Functional Ecology, Department of Life Sciences, University of Coimbra, Calçada Martim de Freitas, 3000-456 Coimbra, Portugal. ${ }^{5}$ Present Address: Mascoma LLC (Lallemand, Inc.), 67 Etna Road, Lebanon, NH 03766, USA.

${ }^{6}$ Present Address: Faculty of Engineering, Bioengineering Department, Recep Tayyip Erdogan University, 53100 Rize, Turkey.

\section{Acknowledgements}

The authors would like to thank the National Plant Phenomics Centre, IBERS, Aberystwyth University, for generating the $\mu \mathrm{CT}$ images, in particular Karen Askew and Candida Nibau. X-ray micro computed tomography scanning work was funded by BBSRC Grant BB/J004464/1.

\section{Competing interests}

The authors declare that they have no competing interests.

\section{Availability of data and materials}

The datasets used and/or analysed during the current study are available from the corresponding authors on reasonable request.

\section{Consent for publication \\ Not applicable.}

\section{Ethics approval and consent to participate} Not applicable.

\section{Funding}

This work was supported by European Regional Development Funding through the Welsh Government for BEACON, Grant Number 8056; the Biotechnology and Biological Sciences Research Council (BBSRC) Institute Strategic Programme Grant on Energy Grasses \& Biorefining (BBS/E/W/10963A01), the BBSRC Core Strategic Programme in Resilient Crops (BB/CSP1730/1) and the Office of Science (BER) Department of Energy, Grant DE-SC0006621. Glycome profiling studies were supported by the BioEnergy Science Center (BESC), Oak Ridge National Laboratory and funded by a Grant (DE-AC05-00OR22725) from the Office of Biological and Environmental Research, Office of Science, U.S. Department of Energy. Generation of the CCRC series of monoclonal antibodies used in this work was supported by the NSF Plant Genome Program (DBI0421683 and IOS-0923992). We acknowledge BBSRC 'Sparking Impact'funding and a Society for Experimental Biology Travel Fund to enable a research visit of RC to the CCRC, University of Georgia.

\section{Publisher's Note}

Springer Nature remains neutral with regard to jurisdictional claims in published maps and institutional affiliations.

Received: 12 February 2019 Accepted: 5 April 2019

Published online: 15 April 2019

\section{References}

1. Yukhananov A, Volcovici V. World Bank to limit financing of coal-fired plants. In: REUTERS. Washington, USA. 2013. https://www.reuters.com/ article/us-worldbank-climate-coal/world-bank-to-limit-financing-ofcoal-fired-plants-idUSBRE96F19U20130716 Accessed 16 July 2013.

2. Rose M, Melander I. World Bank to cease financing upstream oil and gas after 2019. In: REUTERS. Paris, France. 2017. https://www.reuters.com/ article/us-climatechange-summit-worldbank/world-bank-to-cease 
-financing-upstream-oil-and-gas-after-2019-idUSKBN1 E61 LE. Accessed 12 Dec 2017.

3. Glaser MB. CO2 greenhouse effect: technical review. New Jersey: EXXON Research and Engineering Company; 1982.

4. Jacobs RPWM, Griffiths MH, Bright PE, Homer JB, van Oudenhoven ACM, Waller J. The greenhouse effect. The Hague: Shell Internationale Petroleum; 1988.

5. IPCC. 2018. Summary for Policymakers. In: Allen M, Babiker M, Chen Y, de Coninck H, Connors S, van Diemen R, Dube OP, Ebi K, Engelbrecht F, Ferrat $\mathrm{M}$ et al. Global warming of $15^{\circ} \mathrm{C}$ : an IPCC special report on the impacts of global warming of $15^{\circ} \mathrm{C}$ above pre-industrial levels and related global greenhouse gas emission pathways, in the context of strengthening the global response to the threat of climate change, sustainable development, and efforts to eradicate poverty. Geneva: IPCC.

6. Searchinger T, Heimlich R, Houghton RA, Dong F, Elobeid A, Fabiosa J, Tokgoz S, Hayes D, YU T-H. Use of US croplands for biofuels increases greenhouse gases through emissions from land-use change. Science. 2008;319(5867):1238-40.

7. Feng Q, Chaubey I, Cibin R, Engel B, Sudheer KP, Volenec J, Omani N. Perennial biomass production from marginal land in the Upper Mississippi River Basin. Land Degrad Dev. 2018;29(6):1748-55.

8. Marriott PE, Gomez LD, McQueen-Mason SJ. Unlocking the potential of lignocellulosic biomass through plant science. New Phytol. 2016;209(4):1366-81.

9. Kim S, Dale BE. Potential job creation in the cellulosic biofuel industry: the effect of feedstock price. Biofuels Bioprod Biorefining. 2015;9(6):639-47.

10. Ragauskas AJ, Beckham GT, Biddy MJ, Chandra R, Chen F, Davis MF Lignin valorization: improving lignin processing in the biorefinery. Science. 2014:344:1246843.

11. McCann MC, Carpita NC. Biomass recalcitrance: a multi-scale, multifactor and conversion-specific property. J Exp Bot. 2015;66(14):4109-18.

12. Song Y, Mobley JK, Motagamwala AH, Isaacs M, Dumesic JA, Ralph J, Lee AF, Wilson K, Crocker M. Gold-catalyzed conversion of lignin to low molecular weight aromatics. Chem Sci. 2018;9:8127-33.

13. de Vrije T, de Haas GG, Tan GB, Keijsers ERP, Claassen PAM. Pretreatment of Miscanthus for hydrogen production by Thermotoga elfii. Int I Hydrogen Energy. 2002;27(11-12):1381-90.

14. Sørensen A, Teller P, Hilstrom T, Ahring B. Hydrolysis of Miscanthus for bioethanol production using dilute acid presoaking combined with wet explosion pre-treatment and enzymatic treatment. Bioresour Technol. 2008;99:6602-7.

15. Carroll A, Somerville C. Cellulosic biofuels. Annu Rev Plant Biol. 2009;60(1):165-82.

16. Brosse N, Dufour A, Meng X, Sun Q, Ragauskas A. Miscanthus: a fastgrowing crop for biofuels and chemicals production. Biofuels Bioprod Biorefining. 2012;6(5):580-98.

17. Lewandowski I, Clifton-Brown JC, Scurlock JMO, Huisman W. Miscanthus: European experience with a novel energy crop. Biomass Bioenergy. 2000;19(4):209-27.

18. Lee WC, Kuan WC. Miscanthus as cellulosic biomass for bioethanol production. Biotechnol J. 2015;10(6):840-54.

19. Li X, Liao H, Fan C, Hu H, Li Y, Li J, Yi Z, Cai X, Peng L, Tu Y. Distinct geographical distribution of the Miscanthus accessions with varied biomass enzymatic saccharification. PLoS ONE. 2016;11(8):e0160026.

20. Lewandowski I, Clifton-Brown J, Trindade LM, van der Linden GC, Schwarz K-U, Müller-Sämann K, Anisimov A, Chen CL, Dolstra O, Donnison IS, et al. Progress on optimizing Miscanthus biomass production for the European bioeconomy: results of the EU FP7 Project OPTIMISC. Front Plant Sci. 2016;7:1620.

21. Chen C-L, van der Schoot H, Dehghan S, Alvim Kamei CL, Schwarz K-U, Meyer H, Visser RGF, van der Linden CG. Genetic diversity of salt tolerance in Miscanthus. Front Plant Sci. 2017:8:187.

22. da Costa RMF, Simister R, Roberts LA, Timms-Taravella E, Cambler AB, Corke FMK, Han J, Ward RJ, Buckeridge MS, Gomez LD, et al. Nutrient and drought stress: implications for phenology and biomass quality in Miscanthus. Ann Bot. 2018;1:1. https://doi.org/10.1093/aob/mcy15 5 .

23. da Costa RMF, Pattathil S, Avci U, Lee SJ, Hazen SP, Winters A, Hahn MG, Bosch M. A cell wall reference profile for Miscanthus bioenergy crops highlights compositional and structural variations associated with development and organ origin. New Phytol. 2017:213(4):1710-25.

24. da Costa RMF, Lee SJ, Allison GG, Hazen SP, Winters A, Bosch M. Genotype, development and tissue-derived variation of cell-wall properties in the lignocellulosic energy crop Miscanthus. Ann Bot. 2014;114(6):1265-77.

25. Park YB, Cosgrove DJ. Xyloglucan and its interactions with other components of the growing cell wall. Plant Cell Physiol. 2015;56(2):180-94.

26. Slavov G, Robson P, Jensen E, Hodgson E, Farrar K, Allison G, Hawkins S, Thomas-Jones S, Ma XF, Huang L, et al. Contrasting geographic patterns of genetic variation for molecular markers vs phenotypic traits in the energy grass Miscanthus sinensis. Glob Change Biol Bioenergy. 2013:5(5):562-71.

27. da Costa RMF, Allison GG, Bosch M. Cell wall biomass preparation and Fourier transform mid-infrared (FTIR) spectroscopy to study cell wall composition. Bio-protocol. 2015;5(11):e1494. http://www.bio-protocol. org/e1494.

28. Pattathil S, Avci U, Baldwin D, Swennes AG, McGill JA, Popper Z, Bootten T, Albert A, Davis RH, Chennareddy C, et al. A comprehensive toolkit of plant cell wall glycan-directed monoclonal antibodies. Plant Physiol. 2010;153(2):514-25.

29. Pattathil S, Avci U, Miller J, Hahn MG. Immunological approaches to plant cell wall and biomass characterization: glycome profiling. In: Himmel ME, editor. Biomass conversion: methods and protocols. New York: Humana Press; 2012. p. 61-72.

30. Dallabernardina P, Ruprecht C, Smith PJ, Hahn MG, Urbanowicz BR, Pfrengle F. Automated glycan assembly of galactosylated xyloglucan oligosaccharides and their recognition by plant cell wall glycandirected antibodies. Org Biomol Chem. 2017;15(47):9996-10000.

31. Ruprecht C, Bartetzko MP, Senf D, Dallabernadina P, Boos I, Andersen MCF, Kotake T, Knox JP, Hahn MG, Clausen MH, et al. A synthetic glycan microarray enables epitope mapping of plant cell wall glycan-directed antibodies. Plant Physiol. 2017;175(3):1094-104.

32. Meikle PJ, Hoogenraad NJ, Bonig I, Clarke AE, Stone BA. A $(1 \rightarrow 3,1 \rightarrow 4)$ - $\beta$-glucan-specific monoclonal antibody and its use in the quantitation and immunocytochemical location of $(1 \rightarrow 3,1 \rightarrow 4)$ - $\beta$-glucans. Plant J. 1994;5(1):1-9.

33. Puhlmann J, Bucheli E, Swain MJ, Dunning N, Albersheim P, Darvill AG, Hahn MG. Generation of monoclonal antibodies against plant cell-wall polysaccharides (I. Characterization of a monoclonal antibody to a terminal [alpha]-( $1 \rightarrow 2)$-linked fucosyl-containing epitope. Plant Physiol. 1994;104(2):699-710.

34. Steffan W, Kovac P, Albersheim P, Darvill AG, Hahn MG. Characterization of a monoclonal antibody that recognizes an arabinosylated $(1 \rightarrow 6)$-beta-D-galactan epitope in plant complex carbohydrates. Carbohydr Res. 1995;275(2):295-307.

35. Cohen J. Eta-squared and partial eta-squared in fixed factor ANOVA designs. Educ Psychol Meas. 1973;33(1):107-12.

36. Levine TR, Hullett CR. Eta squared, partial eta squared, and misreporting of effect size in communication research. Hum Commun Res. 2002;28(4):612-25.

37. Hughes N, Askew K, Scotson CP, Williams K, Sauze C, Corke F, Doonan $\mathrm{JH}$, Nibau C. Non-destructive, high-content analysis of wheat grain traits using X-ray micro computed tomography. Plant Methods. 2017;13:76.

38. Schindelin J, Arganda-Carreras I, Frise E, Kaynig V, Longair M, Pietzsch T, Preibisch S, Rueden C, Saalfeld S, Schmid B, et al. Fiji: an open-source platform for biological-image analysis. Nat Methods. 2012;9(7):676-82.

39. Avci U, Pattathil S, Hahn MG. Immunological approaches to plant cell wall and biomass characterization: immunolocalization of glycan epitopes. In: Himmel ME, editor. Biomass conversion: methods and protocols. New York: Humana Press; 2012. p. 73-82.

40. Kyriacou A, MacKenzie CR, Neufeld RJ. Detection and characterization of the specific and nonspecific endoglucanases of Trichoderma reesei: evidence demonstrating endoglucanase activity by cellobiohydrolase II. Enzyme Microb Technol. 1987;9(1):25-32.

41. Rosgaard L, Pedersen S, Langston J, Akerhielm D, Cherry JR, Meyer AS. Evaluation of minimal Trichoderma reesei cellulase mixtures on differently pretreated barley straw substrates. Biotechnol Prog. 2007;23(6):1270-6. 
42. Le Ngoc Huyen T, Rémond C, Dheilly RM, Chabbert B. Effect of harvesting date on the composition and saccharification of Miscanthus $\times$ giganteus. Biores Technol. 2010;101(21):8224-31.

43. Lygin AV, Upton J, Dohleman FG, Juvik J, Zabotina OA, Widholm JM, Lozovaya W. Composition of cell wall phenolics and polysaccharides of the potential bioenergy crop-Miscanthus. Glob Change Biol Bioenergy. 2011;3(4):333-45.

44. Wende G, Fry SC. O-feruloylated, O-acetylated oligosaccharides as sidechains of grass xylans. Phytochemistry. 1997;44(6):1011-8.

45. Pauly M, Scheller HV. O-Acetylation of plant cell wall polysaccharides: identification and partial characterization of a rhamnogalacturonan O-acetyl-transferase from potato suspension-cultured cells. Planta. 2000;210(4):659-67.

46. Gille S, Pauly M. O-acetylation of plant cell wall polysaccharides. Front Plant Sci. 2012;3:12.

47. Pawar PM-A, Koutaniemi S, Tenkanen M, Mellerowicz EJ. Acetylation of woody lignocellulose: significance and regulation. Front Plant Sci. 2013;4:118.

48. Agger J, Vikso-Nielsen A, Meyer AS. Enzymatic xylose release from pretreated corn bran arabinoxylan: differential effects of deacetylation and deferuloylation on insoluble and soluble substrate fractions. J Agric Food Chem. 2010;58(10):6141-8.

49. Chen X, Shekiro J, Franden M, Wang W, Zhang M, Kuhn E, Johnson D, Tucker $M$. The impacts of deacetylation prior to dilute acid pretreatment on the bioethanol process. Biotechnol Biofuels. 2012:5(1):8.

50. Busse-Wicher M, Gomes TCF, Tryfona T, Nikolovski N, Stott K, Grantham NJ, Bolam DN, Skaf MS, Dupree P. The pattern of xylan acetylation suggests xylan may interact with cellulose microfibrils as a twofold helica screw in the secondary plant cell wall of Arabidopsis thaliana. Plant J. 2014;79(3):492-506.

51. Saulnier L, Crépeau M-J, Lahaye M, Thibault J-F, Garcia-Conesa MT, Kroon PA, Williamson G. Isolation and structural determination of two 5,5'-diferuloyl oligosaccharides indicate that maize heteroxylans are covalently cross-linked by oxidatively coupled ferulates. Carbohydr Res. 1999:320(1-2):82-92.

52. Grabber JH, Ralph J, Lapierre C, Barrière Y. Genetic and molecular basis of grass cell-wall degradability. I. Lignin-cell wall matrix interactions Comptes Rendus Biologies. 2004;327(5):455-65.

53. Fry SC. Cell wall polysaccharide composition and covalent crosslinking. In: Ulvskov P, editor. Annual plant reviews, plant polysaccharides: biosynthesis and bioengineering, vol. 41. Oxford: Wiley-Blackwell; 2010. p. 1-42.

54. Carpita NC. Structure and biogenesis of the cell walls of grasses. Annu Rev Plant Physiol Plant Mol Biol. 1996;47:445-76.

55. Rancour D, Marita J, Hatfield RD. Cell wall composition throughout development for the model grass Brachypodium distachyon. Front Plant Sci. 2012;3:266

56. Hansen MAT, Ahl LI, Pedersen HL, Westereng B, Willats WGT, Jørgensen $H$, Felby C. Extractability and digestibility of plant cell wall polysaccharides during hydrothermal and enzymatic degradation of wheat straw (Triticum aestivum L.). Ind Crops Prod. 2014:55:63-9.

57. Zhang T, Wyman C, Jakob K, Yang B. Rapid selection and identification of Miscanthus genotypes with enhanced glucan and xylan yields from hydrothermal pretreatment followed by enzymatic hydrolysis. Biotechnol Biofuels. 2012;5(1):56.

58. Li H-Q, Li C-L, Sang T, Xu J. Pretreatment on Miscanthus lutarioriparious by liquid hot water for efficient ethanol production. Biotechnol Biofuels. 2013;6(1):76.

59. Kumar R, Wyman C. Effect of xylanase supplementation of cellulase on digestion of corn stover solids prepared by leading pretreatment technologies. Bioresour Technol. 2009;100(18):4203-13.

60. Qing Q, Yang B, Wyman CE. Xylooligomers are strong inhibitors of cellulose hydrolysis by enzymes. Bioresour Technol. 2010;101(24):9624-30.

61. Suzuki K, Kitamura S, Kato Y, Itoh T. Highly substituted glucuronoarabinoxylans (hsGAXs) and low-branched xylans show a distinct localization pattern in the tissues of Zea mays L. Plant Cell Physiol. 2000;41(8):948-59.

62. Li F, Ren S, Zhang W, Xu Z, Xie G, Chen Y, Tu Y, Li Q, Zhou S, Li Y, et al. Arabinose substitution degree in xylan positively affects lignocellulose enzymatic digestibility after various $\mathrm{NaOH} / \mathrm{H}_{2} \mathrm{SO}_{4}$ pretreatments in Miscanthus. Bioresour Technol. 2013:130:629-37.
63. Lam TBT, Kadoya K, liyama K. Bonding of hydroxycinnamic acids to lignin: ferulic and $p$-coumaric acids are predominantly linked at the benzyl position of lignin, not the $\beta$-position, in grass cell walls. Phytochemistry. 2001;57(6):987-92.

64. Persson P, Andersson J, Gorton L, Larsson S, Nilvebrant N-O, Jönsson L. Effect of different forms of alkali treatment on specific fermentation inhibitors and on the fermentability of lignocellulose hydrolysates for production of fuel ethanol. J Agric Food Chem. 2002;50(19):5318-25.

65. de O Buanafina MM. Feruloylation in grasses: current and future perspectives. Mol Plant. 2009;2(5):861-72.

66. Jönsson L, Alriksson B, Nilvebrant N-O. Bioconversion of lignocellulose: inhibitors and detoxification. Biotechnol Biofuels. 2013:6(1):16.

67. Biely P. Microbial carbohydrate esterases deacetylating plant polysaccharides. Biotechnol Adv. 2012;30(6):1575-88.

68. Grantham NJ, Wurman-Rodrich J, Terrett OM, Lyczakowski JJ, Stott K, luga D, Simmons TJ, Durand-Tardif M, Brown SP, Dupree R, et al. An even pattern of xylan substitution is critical for interaction with cellulose in plant cell walls. Nat Plants. 2017;3(11):859-65.

69. Grohmann K, Mitchell DJ, Himmel ME, Dale BE, Schroeder HA. The role of ester groups in resistance of plant cell wall polysaccharides to enzymatic hydrolysis. Appl Biochem Biotechnol. 1989;20/21(1):45-61.

70. Mitchell DJ, Grohmann K, Himmel ME, Dale BE, Schroeder HA. Effect of the degree of acetylation on the enzymatic digestion of acetylated xylans. J Wood Chem Technol. 1990;10(1):111-21.

71. Kong F, Engler C, Soltes E. Effects of cell-wall acetate, xylan backbone, and lignin on enzymatic hydrolysis of aspen wood. Appl Biochem Biotechnol. 1992;34-35(1):23-35.

72. Selig M, Tucker M, Law C, Doeppke C, Himmel M, Decker S. High throughput determination of glucan and xylan fractions in lignocelluloses. Biotechnol Lett. 2011;33(5):961-7.

73. Ralph J, Quideau S, Grabber JH, Hatfield RD. Identification and synthesis of new ferulic acid dehydrodimers present in grass cell-walls. J Chem Soc Perk T 1. 1994;23:3485-98.

74. Williamson G, Kroon PA, Faulds CB. Hairy plant polysaccharides: a close shave with microbial esterases. Microbiology. 1998;144(Pt 8):2011-23.

75. Kondo T, Mizuno K, Kato T. Cell wall-bound $p$-coumaric and ferulic acids in Italian ryegrass. Can J Plant Sci. 1990;70(2):495-9.

76. Encina A, Fry SC. Oxidative coupling of a feruloyl-arabinoxylan trisaccharide (FAXX) in the walls of living maize cells requires endogenous hydrogen peroxide and is controlled by a low-Mr apoplastic inhibitor. Planta. 2005;223(1):77-89.

77. Bento-Silva A, Vaz Patto MC, do Rosário Bronze M. Relevance, structure and analysis of ferulic acid in maize cell walls. Food Chem. 2018;246:360-78.

78. Fry SC, Nesselrode BHWA, Miller JG, Mewburn BR. Mixed-linkage $(1 \rightarrow 3,1 \rightarrow 4)$ - $\beta$-D-glucan is a major hemicellulose of Equisetum (horsetail) cell walls. New Phytol. 2008;179:104-15.

79. Vega-Sanchez ME, Verhertbruggen Y, Christensen U, Chen X, Sharma V, Varanasi $P$, Jobling SA, Talbot M, White RG, Joo M, et al. Loss of cellulose synthase-like F6 function affects mixed-linkage glucan deposition, cell wall mechanical properties, and defense responses in vegetative tissues of rice. Plant Physiol. 2012;159(1):56-69.

80. Vega-Sánchez ME, Verhertbruggen Y, Scheller HV, Ronald PC. Abundance of mixed linkage glucan in mature tissues and secondary cell walls of grasses. Plant Signal Behav. 2013;8(2):e23143.

81. Biswal AK, Atmodjo MA, Li M, Baxter HL, Yoo CG, Pu Y, Lee Y-C, Mazarei M, Black IM, Zhang J-Y, et al. Sugar release and growth of biofuel crops are improved by downregulation of pectin biosynthesis. Nat Biotechnol. 2018;36:249-57.

82. Atmodjo MA, Hao Z, Mohnen D. Evolving views of pectin biosynthesis. Annu Rev Plant Biol. 2013;64:747-79.

83. Tan L, Eberhard S, Pattathil S, Warder C, Glushka J, Yuan C, Hao Z, Zhu $X$, Avci U, Miller JS, et al. An Arabidopsis cell wall proteoglycan consists of pectin and arabinoxylan covalently linked to an arabinogalactan protein. Plant Cell. 2013;25(1):270-87.

84. Akpanika GA, Winters A, Wilson T, Ayoola GA, Adepoju-Bello AA, Hauck B. Polyphenols from Allanblackia floribunda seeds: identification, quantification and antioxidant activity. Food Chem. 2017;222:35-42.

85. Zeng Y, Zhao S, Yang S, Ding SY. Lignin plays a negative role in the biochemical process for producing lignocellulosic biofuels. Curr Opin Biotechnol. 2014;27:38-45. 
86. Wilkerson CG, Mansfield SD, LU F Withers S, Park J-Y, Karlen SD, Gonzales-Vigil E, Padmakshan D, Unda F, Rencoret J, et al. Monolignol ferulate transferase introduces chemically labile linkages into the lignin backbone. Science. 2014;344(6179):90-3

87. Crowe JD, Feringa N, Pattathil S, Merritt B, Foster C, Dines D, Ong RG, Hodge DB. Identification of developmental stage and anatomical fraction contributions to cell wall recalcitrance in switchgrass. Biotechnol Biofuels. 2017;10(1):184.

88. Donald CM. The breeding of crop ideotypes. Euphytica. 1968;17(3):385-403.

89. Martre P, Quilot-Turion B, Luquet D, Memmah M-MO-S, Chenu K Debaeke P. Model-assisted phenotyping and ideotype design. In: Sadras VO, Calderini DF, editors. Crop physiology. 2nd ed. San Diego: Academic Press; 2015. p. 349-73.

90. Ralph J, Brunow G, Boerjan W. Lignins. In: Encyclopedia of life sciences. Chichester: Wiley; 2007.

91. Ralph J, Grabber JH, Hatfield RD. Lignin-ferulate cross-links in grassesactive incorporation of ferulate polysaccharide esters into ryegrass lignins. Carbohyd Res. 1995;275(1):167-78.

92. Nguyen NA, Barnes SH, Bowland CC, Meek KM, Littrell KC, Keum JK, Naskar AK. A path for lignin valorization via additive manufacturing of high-performance sustainable composites with enhanced 3D printability. Sci Adv. 2018;4(12):eaat4967.

93. van der Weijde T, Kamei CLA, Severing El, Torres AF, Gomez LD, Dolstra O, Maliepaard CA, McQueen-Mason SJ, Visser RGF, Trindade LM. Genetic complexity of miscanthus cell wall composition and biomass quality for biofuels. BMC Genomics. 2017:18(1):406.

94. Busse-Wicher M, Grantham NJ, Lyczakowski JJ, Nikolovski N, Dupree P. Xylan decoration patterns and the plant secondary cell wall molecular architecture. Biochem Soc Trans. 2016;44(1):74-8.

95. Busse-Wicher M, Li A, Silveira RL, Pereira CS, Tryfona T, Gomes TC, Skaf MS, Dupree P. Evolution of xylan substitution patterns in gymnosperms and angiosperms: implications for xylan interaction with cellulose. Plant Physiol. 2016;171(4):2418-31.

96. Lefebvre V, Fortabat M-N, Ducamp A, North HM, Maia-Grondard A, Trouverie J, Boursiac Y, Mouille G, Durand-Tardif M. ESKIMO1 disruption in arabidopsis alters vascular tissue and impairs water transport. PLoS ONE. 2011:6(2):e16645.

97. Manabe Y, Nafisi M, Verhertbruggen Y, Orfila C, Gille S, Rautengarten C, Cherk C, Marcus SE, Somerville S, Pauly M, et al. Loss-of-function mutation of REDUCED WALL ACETYLATION2 in Arabidopsis leads to reduced cell wall acetylation and increased resistance to Botrytis cinerea. Plant Physiol. 2011;155(3):1068-78.

98. Chang VS, Holtzapple MT. Fundamental factors affecting biomass enzymatic reactivity. Appl Biochem Biotechnol. 2000;84-86:5-37.
99. Bellissimi E, Van Dijken JP, Pronk JT, Van Maris AJA. Effects of acetic acid on the kinetics of xylose fermentation by an engineered, $x y l o s e-$ isomerase-based Saccharomyces cerevisiae strain. FEMS Yeast Res. 2009;9(3):358-64

100. Mira NP, Teixeira MC, Sa-Correia I. Adaptive response and tolerance to weak acids in Saccharomyces cerevisiae: a genome-wide view. OMICS. 2010:14(5):525-40.

101. Pawar PM-A, Derba-Maceluch M, Chong S-L, Gandla ML, Bashar SS, Sparrman T, Ahvenainen P, Hedenström M, Özparpucu M, Rüggeberg M. In muro deacetylation of xylan affects lignin properties and improves saccharification of aspen wood. Biotechnol Biofuels. 2017;10(1):98

102. Himmel ME, Ding S-Y, Johnson DK, Adney WS, Nimlos MR, Brady JW, Foust TD. Biomass recalcitrance: engineering plants and enzymes for biofuels production. Science. 2007;315(5813):804-7.

103. Yoshida M, Liu Y, Uchida S, Kawarada K, Ukagami Y, Ichinose H, Kaneko S, Fukuda K. Effects of cellulose crystallinity, hemicellulose, and lignin on the enzymatic hydrolysis of Miscanthus sinensis to monosaccharides. Biosci Biotechnol Biochem. 2008;72(3):805-10.

104. Rao RS, Prakasham RS, Prasad KK, Rajesham S, Sarma PN, Rao LV. Xylitol production by Candida sp.: parameter optimization using Taguchi approach. Process Biochem. 2004;39(8):951-6.

105. Somani A, Smith D, Hegarty M, Fernandez-Fuentes N, Ravella SR, Gallagher JA, Bryant DN. Draft genome assemblies of xylose-utilizing Candida tropicalis and Candida boidinii with potential application in biochemical and biofuel production. Genome Announc. 2018:6(7):e01594-617.

106. Walker DJ, Gallagher J, Winters A, Somani A, Ravella SR, Bryant DN. Process optimization of steam explosion parameters on multiple lignocellulosic biomass using Taguchi method-a critical appraisal. Front Energy Res. 2018:6(46):1-13. https://doi.org/10.3389/fenrg.2018.00046

107. Parveen I, Wilson T, Donnison IS, Cookson AR, Hauck B, Threadgill MD. Potential sources of high value chemicals from leaves, stems and flowers of Miscanthus sinensis 'Goliath' and Miscanthus sacchariflorus. Phytochemistry. 2013;92:160-7.

108. Parveen I, Wilson T, Threadgill MD, Luyten J, Roberts RE, Robson PR, Donnison IS, Hauck B, Winters AL. Screening for potential co-products in a Miscanthus sinensis mapping family by liquid chromatography with mass spectrometry detection. Phytochemistry. 2014;105:186-96.

109. Lewandowski I, Clifton-Brown J, Kiesel A, Hastings A, labal Y. Miscanthus. In: Alexopoulou E, editor. Perennial Grasses for Bioenergy and Bioproducts. London: Academic Press; 2018. p. 35-55.

110. Hodkinson TR, Klaas M, Jones MB, Prickett R, Barth S. Miscanthus: a case study for the utilization of natural genetic variation. Plant Genet Resour. 2014;13(3):219-37.
Ready to submit your research? Choose BMC and benefit from:

- fast, convenient online submission

- thorough peer review by experienced researchers in your field

- rapid publication on acceptance

- support for research data, including large and complex data types

- gold Open Access which fosters wider collaboration and increased citations

- maximum visibility for your research: over 100M website views per year

At $\mathrm{BMC}$, research is always in progress.

Learn more biomedcentral.com/submissions 